\title{
Tóth Anikó Panna: A szociális szakemberek digitális technológia és közösségi média használata
}

\begin{abstract}
Absztrakt
A tanulmányban a szociális szakemberek digitális technológia és közösségi média használatát vizsgáló kutatás eredményei kerülnek bemutatásra. A kutatás kvantitatív módszerrel zajlott, 337 fö töltötte ki az online kérdőívet. Vizsgáltam a szociális szakemberek attitüdjeit és igényeit, informatikai jártasságát, digitális mủveltségét, a közösségi média használat jellemzőit, különös tekintettel a kliensekkel való online kapcsolatra és a tudatos médiahasználatra. Az eredmények szerint a szociális szakemberek attitűdjei pozitívak a technológia használattal kapcsolatban. A kliensekkel való online kapcsolattartás igen elterjedt, azonban a válaszadók szerint az intézmények többségében erre vonatkozóan nincs semmilyen ajánlás vagy szabályozás. Informatikai, digitális kompetencia fejlesztő képzésen 10-ből 7 válaszadó soha nem vett részt és a legtöbben úgy látják, hogy tanulmányaik során sem kaptak megfelelő felkészítést az infokommunikációs technológiák használatára vonatkozóan. Igényük lenne új eszközök és programok beszerzésének támogatására, valamint útmutatókra, ajánlásokra a segítők technológia és közösségi média használatára vonatkozóan. A tanulmány a kutatási eredmények összefoglalásával és fejlesztési javaslatok megfogalmazásával zárul.
\end{abstract}

Kulcsszavak: szociális munka, etika, digitális technológia, IKT, közösségi média

\begin{abstract}
The study presents the results of research on the use of digital technology and social media by social professionals. The research was carried out using a quantitative method, 337 social professionals filled out the questionnaire. I examined the attitudes and needs of social professionals, IT proficiency, digital literacy, characteristics of social media use, with reference to online contact with clients and conscious media use. According to the results, the attitudes of social professionals are positive about the use of technology. Online contact with clients is very common, however, most institutions do not have any recommendations or regulations in this regard. 7 out of 10 respondents never participated in IT, digital competence development training and most of them consider that they did not receive adequate training in the use of info communication technologies during their studies. They see a need to support the procurement of new tools and programs and they would need guidelines, recommendations on the use of technology and social media. The study concludes with a summary of the research results and the formulation of development proposals.
\end{abstract}

Keywords: social work, ethics, digital technology, ICT, social media 


\section{Bevezetés}

A tanulmányban a szociális szakemberek digitális technológia és közösségi média használatát vizsgáló kutatás legfontosabb eredményei kerülnek bemutatásra. A kutatás célja volt annak megismerése, hogy munkájuk során a szociális szakemberek milyen mértékben és milyen formában használnak infokommunikációs technológiákat, illetve, hogy ezzel kapcsolatban milyen tapasztalataik vannak. Felmértem a szociális ágazatban dolgozó szakemberek attitüdjeit és igényeit, informatikai jártasságát, digitális müveltségét, a közösségi média használat jellemzőit, különös tekintettel a kliensekkel való online kapcsolatra és a tudatos médiahasználatra. Kutatásomban a kliens-segítő közötti kapcsolatra és kommunikációra, a közösségi média használatra, az online jelenlét vizsgálatára, etikai kérdésekre fókuszáltam. Az igények felmérése mellett célom volt azonosítani azokat az akadályozó tényezőket, melyek az IKT szociális munka gyakorlatába való integrációja előtt állnak. Ezzel szeretnék hozzájárulni a szociális munka gyakorlatának fejlesztéséhez, azáltal, hogy elöször is reális képet kapunk a szociális munkások és gondozók IKT használatáról.

A témaválasztást indokolta, hogy a magyar szociális szakemberek információs technológia használatáról keveset tudunk, csak néhány kutatás folyt ebben a témában, azok is a kétezres évek közepén (Héra - Ligeti 2005; Molnár 2006; Kéthelyi - Székely 2007; Rácz - Gyarmati 2008). Az utóbbi években jelentős változások történtek, elterjedtek az okostelefonok, a vezeték nélküli internetezés, a közösségi média használat, ezek hatásairól minimális ismeretünk van. A kutatás tervezésekor feltételeztem, hogy ugrásszerüen megnőtt a kliens-segítő online „találkozások” száma, ami hatott a kliens-segítő kapcsolatra, célom volt megvizsgálni, hogy ez valóban így van-e és ha igen, a segítőknek milyen tapasztalatai vannak ezen a téren. Indokolta témaválasztásomat a téma aktualitása is, hiszen tudjuk, hogy a telemedicina ellátások dinamikusan fejlődnek, terjednek világszerte, itthon azonban mind az IKT használatának lehetőségeivel összefüggő ismeretekben, mind az alkalmazásban jelentősek a hiányok, különösen szociális területen. Kutatásom relevanciáját az is alátámasztotta, hogy nem csak az IKT használatban rejlö lehetőségekről készült hazánkban kevés tanulmány, szakmai kiadvány, de a technológia használat potenciális veszélyeivel, az ezzel kapcsolatos kihívásokkal is kevesen foglalkoznak. A magyar szakmai szervezetek ${ }^{1}$ nem fogalmaztak meg útmutatókat, ajánlásokat a segítőknek a technológia és közösségi média használatára vonatkozóan, a képzésben sem jelentek meg elég hangsúllyal az erről szóló ismeretek.

\section{Elméleti háttér, a kutatás témája és kérdései}

A témának - infokommunikációs technológiák használata a szociális munka gyakorlatában, az erre vonatkozó szakmai ajánlások bemutatása, felmerülő etikai kérdések és dilemmák vizsgálata, a mentálhigiéné fejlesztésének lehetőségei a telemedicina segítségével - jelentős szakirodalma van, melyet már áttekintettem, összefoglaltam az irodalomjegyzékben feltüntetett publikációimban. Ebben a tanulmányban csak azokat a fogalmakat, elméleteket és kutatási eredményeket emelem ki, melyek jelen kutatásom témájához a legszorosabban kapcsolódnak, amelyek a kutatási kérdések megfogalmazásában kiindulópontot jelentettek.

Tekintsük át tehát röviden, hogy a szakirodalom alapján mit is tudunk a szociális szakemberek digitális technológia használatáról és a digitális egyenlőtlenségekről!

1 Szemben a nemzetközi gyakorlattal, melyet bemutattam korábbi publikációimban, lásd bővebben Tóth 2017 a,b,c. 
Ha valaki használni szeretné a technológiát először is hozzáférésre van szüksége. A kliensek és segítők hozzáférése a digitális technológiához gyakran limitált, hiszen a kliensek nagy része hátrányos helyzetü, a szociális területen pedig nem mindig megfelelőek a munkakörülmények, sokan nem jutnak számítógéphez vagy okos eszközökhöz, ha használnak is IKT eszközöket, általában nem a legmodernebbet, a technikai támogatás és a megfelelő adatvédelem nem mindig megoldott. Ennek ellenére azt mondhatjuk, hogy a szociális munkásoknak tenniük kell a digitális szakadék csökkentéséért, a saját hozzáférésük megteremtéséért, hiszen enélkül segíteni sem tudnak másokon és a klienseik hozzáférésének és IKT használatának elösegítéséért is tenniük kell, hiszen ez ma már a teljes társadalmi részvétel feltétele. Meg kell vizsgálnunk, hogy milyen akadályok állnak a kliens hozzáférése előtt és amennyiben lehetséges, meg kell oldanunk ezeket a problémákat (NASW\&ASWB 2005, BASW 2012, Tóth 2017c).

A hozzáférés persze önmagában még nem elegendő. A technológia használatához a felhasználónak az eszközökön vagy legalábbis a hozzáférésen túl rendelkeznie kell a szükséges készségekkel és képességekkel is. A technológia alkalmazásának terjedéséhez, a digitális szakadék csökkentéséhez nem elegendő a megfelelő infrastruktúra és a technikai kompetencia - az, hogy képesek vagyunk használni az adott technológiát -, hanem a felhasználóknak, a szakembereknek digitális irástudással, információs és kommunikációs technológiai müveltséggel (literacy) is bírniuk kell. Az IKT-müveltség összetevői: képesség elérni, kezelni, integrálni, kiértékelni és létrehozni információkat (Boutin, Chinien 2003). Mishna és szerzőtársai, Bullock és Colvin felhívták rá a figyelmet, hogy a szociális szakemberek digitális kompetenciái nem egyformák, egy részük már magabiztosan eligazodik a közösségi médiában, mások ódzkodnak a használatától. Ez függ a generációs különbségektöl (Mishna et al. 2014; Bullock, Colvin 2015), a segítők iskolai végzettségétől és attitüdjeitől is.

$\mathrm{Az}$ is nagyon fontos, hogy milyen céllal, milyen tevékenységek végzésére használja valaki a technológiát. DiMaggio és Hargittai a digitális egyenlőtlenségek mélyreható elemzéséhez öt dimenzió vizsgálatát javasolták, ezek a technikai felszereltség, eszközellátottság (nem csak mennyiséget, hanem minőséget is vizsgálva), a használat autonómiája, a használathoz szükséges készségek, a társas támogatás, a technológia használat céljai (DiMaggio - Hargittai 2001).

Az is vizsgálandó, hogy egyáltalán szeretnénk-e használni a technológiát, milyen attitüdjeink vannak ezzel kapcsolatosan. „A digitális választás kifejezés definiálja azt a jelenséget, amikor valakinek módjában áll az innováció elfogadása, az új technológia alkalmazása, de tudatos döntés eredményeképpen nem használja." (Erdős 2015: 5) A szociális szakemberek attitüdjeinek kapcsán Belluomini írt egy érdekes cikket, ami szerint az infokommunikációs technológia szociális munka gyakorlatába történő integrálásával kapcsolatos hozzáállás lehet proaktív, reaktív és elutasító. Proaktívak vagyunk, mikor olvassuk a friss szakirodalmat, elgondolkodunk azon, hogy a technológia használata hogyan hat a gyakorlati munkákra, hogyan lehetne a kliensek érdekképviseletére és segítésére felhasználni. szívesen kipróbálunk új dolgokat. Természetesen a kritikus gondolkodás is fontos, sokan mérlegelik a technológia használatát, megfontoltak, csak a már „bevált”, tesztelt, szakmailag elfogadott módszereket veszik át. Elutasító a viselkedésünk például olyan helyzetekben, amikor úgy gondoljuk, hogy a technológia használata kontraindikált, vagy van más, a kliens számára megfelelőbb beavatkozási forma, vagy esetleg azért nem használjuk a technológiát, mert a feltételek nem adottak hozzá. Létezik tagadó hozzáállás is, ami több az elutasításnál, aki tagadó hozzáállású egyáltalán nem „hisz” a technológia használatának létjogosultságában a szociális munka terén (Belluomini 2013). Sok szociális munkás az elsősorban adatgyüjtésre fókuszáló technológia használatot utasítja el, mert úgy gondolják, hogy ettől a klienseik életminősége nem fog javulni és a szolgáltatások hatékonyságát sem növeli (Bullock, Colvin 2015). Sokan úgy érzik, hogy az adminisztráció elveszi a kliensektől az időt, és ettől bürokratának érzik magukat, úgy 
gondolják, hogy ez csak nehezíti az életüket. Nem látják a megfelelö dokumentáció, adatrögzítés értelmét, szerepét, mert a vezetők, menedzserek, döntéshozók nem vonják be öket megfelelően a rendszerek tervezésébe, és nem kapnak visszajelzést, hogy mire használják fel a megadott adatokat, így nem is motiváltak az elektronikus nyilvántartási rendszerek használatában (Readron 2010).

Perron és szerzőtársai úgy látják, hogy a szociális munkások képzésében és gyakorlatában nem jelent meg kellö súllyal az IKT használata, ami azt a veszélyt hordozza, hogy nem leszünk eléggé versenyképesek az egészségügyi és pszichoszociális szolgáltatások nyújtásában. Megfelelő képzés nélkül pedig fennáll a veszélye, hogy a szociális munkások alacsony színvonalú online szolgáltatásokat kezdenek el végezni, amiből jogi és etikai problémák származhatnak. (Perron, Taylor, Glass, Margerum-Leys 2010). A képzésben a technikai kompetenciák fejlesztésére, az IKT-müveltség megszerzésére, az etikai kérdések megtárgyalására, azonosítására, a mentálhigiénés szemlélet elsajátítására is nagyobb hangsúlyt kell helyezni. Az IKT-műveltség megszerzésében szerepe van a megfelelő képzésnek, az egész életen át tartó tanulásnak, a folyamatos továbbképzésnek, önképzésnek, amire az internet és az IKT segítségével számtalan lehetőség adódik (Perron, Taylor, Glass, Margerum-Leys 2010). Fontos lenne, hogy a (leendő) szociális szakemberek tudják, hogy a kliensek segítésében, forrásteremtésben, érdekképviseletben milyen lehetöséget rejt az IKT (és különösen a közösségi média) használata, ismerjenek meg jól müködő projekteket, jó gyakorlatokat, legyenek képesek végiggondolni az online tevékenységeik, jelenlétük szakmai, etikai vonatkozásait, tisztában legyenek az online kommunikáció sajátosságaival. (Tóth 2017c) A brit szociális munkások szakmai szervezete, a BASW szerint a szociális szakemberek egyre több tanulási, képzési lehetőséghez, tananyaghoz, előadáshoz, szakmai hírhez férhetnek hozzá a közösségi médiában, amely lehetöséget biztosít a folyamatos tanulásra, szakmai fejlődésre, a szociálismunkás-identitás erősítésére. Megfelelően használva a közösségi média remek eszköz lehet a szakmai közösség fejlesztésére. Lehetővé válik a fontos, aktuális ügyek megvitatása, információk cseréje, a tudás megosztása, kapcsolatteremtés hasonló érdeklődésű kollégákkal, társszakmák képviselőivel (BASW 2012, Tóth 2017c).

Mindezek alapján fogalmaztam meg kutatási kérdéseimet. A szociális szakembereket, a kliensekkel való online segítői kapcsolatot, a felmerülő etikai kérdéseket, dilemmákat helyeztem a középpontba. Fontos volt, hogy felmérjem mennyire jellemző egyáltalán a kliensekkel való online kapcsolattartás, az online konzultáció, a közösségi média és a technológia használata a szociális munkában és a gondozásban, hogy a segítők milyen előnyeit és hátrányait látják mindezeknek. A kliensekkel való online kapcsolatra vonatkozó kérdések összeállításában inspirált Kolmes és Taube 2013-as kutatása, melyben mentálhigiénés szakembereket, képzett pszichoterapeutákat kérdeztek arról, hogy keresték-e vagy találták-e meg véletlenül kliensüket, kliensük adatait online. Eredményeik szerint a segítők $48 \%$-a keresett már rá kliensére a neten, és $28 \%$-uk botlott bele véletlenül kliense adataiba, blogjába, profiljába a világhálón. A legtöbben úgy gondolják, hogy a klienssel kapcsolatos online információk keresése hasznos volt, bár belátják, hogy ez egy kis határátlépéssel járt. Néhány segítő úgy gondolja, hogy joga van ilyen információk keresésére, hogy az támogatta a munkájukat, segítette őket abban, hogy megértsék a klienst, jobban bízzanak benne, hogy jobban tudják támogatni. Mások kizárólag krízishelyzetben keresnének így információt. A legtöbb válaszadó szerint a felfedezett információknak nincs hatása a kezelésre, a segítő kapcsolatra, akik szerint viszont van, azok pozitívnak ítélik a hatást. Elgondolkodtató, hogy bár így gondolják, mégis nagyon kevesen mondták el kliensüknek, hogy rákerestek az interneten. A válaszadók egy része negatív érzésekről számolt be, úgy érzi, elárulta a klienst, kémkedett utána, rombolja a köztük lévő bizalmi kapcsolatot az, hogy rákeresett (Kolmes - Taube 2014). Erre vonatkozóan én is tettem fel kérdéseket, mert nagyon érdekesnek tartom etikai 
szempontból ezt a témát, illetve megdöbbentőnek az eredményeiket, szerettem volna képet kapni a digitalizáció szociális munkára gyakorolt hatásairól.

A segítők hozzáférésének vizsgálatához kérdéseket tettem fel az eszközellátottsággal, infrastruktúrával, technikai támogatással kapcsolatban, a fogyatékossággal élő kliensek hozzáférésének felméréséhez pedig az intézmények, ellátások weboldalának akadálymentességére kérdeztem rá. Felmértem hogyan értékelik a segítők készségeiket, a digitális kompetenciák szintjében valóban megfigyelhetőek-e generációs és egyéb különbségek. Kíváncsi voltam rá, hogy milyen tevékenységek végzésére használják a digitális technológiát és a közösségi médiát, megkülönböztetve szakmai és magánjellegű használatot. A korábbi magyar kutatások (Héra, Ligeti 2005; Kéthelyi, Székely 2007; Rácz, Gyarmati 2008) az eszközellátottság és használat felmérésére vonatkozóan jó kiindulópontot jelentettek, természetesen figyelembe kellett vennem az utóbbi évtizedben lezajlott technológiai változásokat - pl. okoseszközök megjelenése - és a közösségi média használat berobbanását. Tesztelni szerettem volna az említett korábbi hazai kutatásokon alapuló a feltételezésemet is, hogy a szociális ágazatban gyakran elavult eszközöket és rendszereket használnak, a rendszeres karbantartásra ritkán van lehetőség, külön IT szakembert kevesen tudnak alkalmazni, így általában a kollégák közül valaki vállalja fel, hogy munkaidőben ellátja a rendszergazdai feladatokat is: telepíti, frissíti a szükséges szoftvereket, frissíti a honlapot és a közösségi médiafelületeket, mert ezen tevékenységek finanszírozása nem megoldott. (Tóth 2017c) Tehát annak felmérése is fontos volt számomra, hogy kapnak-e segítséget a technológia használathoz a segítők (külön kérdés vonatkozott a technikai jellegű segítségre, rendszergazda meglétére, illetve szakmai, módszertani, etikai ,iránymutatásra” intézményi és ágazati szinten).

Kutatásom egyik fontos célja és kérdése volt a szociális szakemberek attitűdjeinek vizsgálata. A digitális választás vizsgálatára az attitüdök kérdésblokkban került sor, a digitális technológia használatot teljes mértékben elutasítók azonban a mintavétel jellegéből adódóan kimaradtak a mintából, erre az eredmények értékelésekor tekintettel kell lennünk. A digitális választás, illetve az attitüdök kapcsán igyekeztem árnyalt képet adni, hiszen azt gondolom, hogy a választás nem csak teljes elutasítást, vagy elfogadást jelenthet, illetve nem is csak háromféle - proaktív, reaktív, elutasító - hozzáállás létezik. Ezért a kérdés vizsgálatához számos pozitív és negatív állítást fogalmaztam meg a technológia használattal, attitűdökkel kapcsolatosan és kértem a válaszadókat, hogy jelöljék 5 fokú skálán mennyire értenek egyet azokkal, illetve külön kérdésekben felmértem a közösségi média használati szokásaikat, tudatosságukat is.

Kíváncsi voltam arra is, hogy mit gondolnak a szakemberek, elegendő hangsúlyt helyeznek-e a szociális képzésben az IKT müveltség fejlesztésére. Ezért kérdéseket tettem fel arra vonatkozóan, hogy érzik a szakemberek, tanulmányaik során felkészítették-e őket a professzionális és etikus, tudatos technológia használatra, hogy részt vettek-e a szakemberek bármilyen ezzel kapcsolatos egyéb képzésen. Szintén vizsgáltam, hogy mit gondolnak arról a válaszadó segítők, milyen módon lehetne felhívni a szociális szakemberek figyelmét a digitális kompetencia fontosságára, hogy lenne-e igényük egyáltalán ilyen jellegü képzéseken való részvételre és ha igen, milyen formában? Vizsgáltam azt a kérdést is, hogy mennyire használják ki a közösségi média által kínált tanulási, képzési, fejlődési lehetőségeket a szociális szakemberek, illetve, hogy egyetértenek-e azzal, hogy ez egy jó lehetőség erre a célra, az önfejlesztésre, a szakmai kapcsolatok ápolására. A közösségi média használatra, a képzési igények, illetve a készségekre vonatkozó kérdések összeállításában - természetesen a hazai sajátosságokhoz igazítva - nagyon nagy segítséget jelentett munkám során a BASW-SCIE legújabb kutatása (http1).

Igényfelméréssel zárult a felmérés, melynek célja az volt, hogy a szociális szakemberek igényeinek összegyüjtésével és bemutatásával segítsem adekvát ágazati fejlesztési célok (az 
infrastruktúra, a képzési és továbbképzési rendszer fejlesztése, szakmai, módszertani fejlesztések stb.) megfogalmazását.

\section{Módszertan}

Kvantitatív kutatást végeztem a hazai, a szociális ágazatban dolgozó szakemberek körében. Önkitöltős - interneten kitölthető - kérdőívekkel történt az adatfelvétel. A vizsgált dimenziók, kérdés-csoportok az alábbiak voltak (a kérdöív is ennek megfelelően tagolódott):

- Szocio-demográfiai dimenzió

- Munkahelyi feltételek, ellátás jellemzői

- Eszközhasználat, infrastruktúra, biztonság és adatvédelem, tudatosság

- IKT jártasság, digitális müveltség, online jelenlét

- Közösségi média használati szokások

- Kliensekkel való online kapcsolat, gondozás, digitális szociális munka elterjedtségének felmérése, jellemzői, pozitív és negatív tapasztalatok összegyüjtése

- Attitüdök és fejlesztési igények

Az alapsokaságot a szociális ágazatban dolgozók alkották, közfoglalkoztatottak nélkül, a KSH adatai szerint 2018-ban ez 101.800 fó volt (http4). A kutatás kezdetekor fontolóra vettem, hogy csak a szociális munkásokat kérem meg, hogy töltsék ki a kérdőívemet, azonban ezt végül több okból is elvetettem. Egyrészt nem egyszerü annak definiálása, hogy kit is tekinthetünk ma szociális munkásnak ${ }^{2}$, másrészt kutatási témám szempontjából mindenképpen fontos volt a szociális ellátásokban dolgozó, nem felsőfokú szociális végzettségű szakemberek, gondozók, szociális munkatársak véleménye, eszközellátottsága, készségeik és attitüdjeik is. Így mindezek miatt végül amellett döntöttem, hogy minden szociális területen dolgozót - a közfoglalkoztatottak kivételével - kérek a válaszadásra. A kérdőív szocio-demográfiai blokkjába a részletesebb elemzés segítésére mindenesetre bekerült két végzettségre vonatkozó kérdés, kértem a válaszadókat végzettségük megnevezésére, illetve megkérdeztem, hogy rendelkeznek-e felsőfokú szociális végzettséggel.

A felhívás az online kérdőív linkjével a Függelék 1. számú táblázatában felsorolt felületeken és időpontokban került megosztásra ${ }^{3}$ és a kitöltésre 2020.02.10-ig volt lehetőség. A cél az volt, hogy minél több szociális szakembert elérjek. A felhívás megosztására a legnagyobb tagságú, követőszámú oldalakat, csoportokat, listákat, illetve a kisebb méretü, de ismert, elismert szakmai szervezetek oldalainak szerkesztőit kértem fel. A fenti csoportokban és oldalakon való megosztással becslésem szerint 20000-25000 föhöz juthatott el potenciálisan a felhívás (figyelembe véve, hogy a különböző csoportok tagjai közt jelentős átfedés lehet.)

A mintavétel jellegéből adódóan vannak a kutatásnak korlátai, reprezentativitásról nem beszélhetünk és a felhívás nem érhette el azokat a szociális szakembereket, akik egyáltalán nem interneteznek, vagy nem tagjai ezen szakmai csoportoknak, levelezőlistáknak, nem használnak

\footnotetext{
${ }^{2}$ A Szociális Szakmai Szövetség által kiadott etikai kódex definíciója szerint "Szociális munkás: szakirányú egyetemi, föiskolai, illetve alapképzésben vagy mesterképzésben szerzett oklevéllel rendelkező munkatárs, aki szociális munkát végez." (3Sz 2016:10) Azonban a szociális ellátásokban az 1/2000. (I. 7.) SzCsM rendelet a személyes gondoskodást nyújtó szociális intézmények szakmai feladatairól és müködésük feltételeiről 3. számú melléklete szerint szociális végzettség nélkül is lehet alkalmazni munkavállalókat szakmai munkakörben a szociális szférában, akik bár a fenti definíció szerint nem szociális munkások, mégis szociális munkásként tekinthetnek önmagukra.

${ }^{3}$ Ezúton is szeretném köszönetemet kifejezni minden szakembernek a válaszadásért, a megosztásért az oldalak, csoportok, levelezőlisták szerkesztőinek, kollégáknak, a tesztelőknek, illetve köszönöm a visszajelzéseket is!
} 
közösségi oldalt ${ }^{4}$, ők nem kerültek a mintába. Az eredmények értékelésénél mindezekre figyelemmel kell lennünk.

A kérdőív a Google Ürlapok program segítségével került megszerkesztésre. A kérdőív előzetesen tesztelésre került, különböző életkorú és ellátástípusban dolgozó szociális szakembereket kértem fel a kitöltésre és vártam visszajelzéseiket. A tesztelés nagyon hasznosnak bizonyult, ez alapján a kérdőívet jelentősen rövidítettem és sok kérdés és válaszlehetőség pontosításra és átfogalmazásra került. A végleges kérdőív kitöltése így is nagyjából 25 percet vett igénybe, ennek tükrében a beérkezett 337 választ sikernek értékelem.

\section{Az eredmények bemutatása}

\section{A válaszadók alapvetö jellemzöi}

A válaszadók 90,8\%-a nő volt, mindössze 9,2\%-a férfi. A nők első ránézésre meglepően magas aránya nem a mintavétel hibájából vagy a nők nagyobb válaszadási hajlandóságából adódik, valójában teljesen megfelel az ágazati statisztikáknak, átlagnak. ${ }^{5}$ Legtöbben a 40-49 év közötti életkorúak közül töltötték ki a kérdőívet, a válaszadók 37,1\%-a tartozott ebbe a korcsoportba, 18 éven aluli válaszadó nem volt, 19-29 év közötti életkorú volt 7,7\%-uk, 30-39 éves a 24\%uk, 50-59 éves korú volt a 24,3\%-uk, 60-64 éves 4,5\%-uk és 65 éves felüli 2,4 \%-uk.

Iskolai végzettséget tekintve a válaszadók 86,3\%-a rendelkezett felsőfokú végzettséggel (54\%a föiskolai, 24,9\% egyetemi, 6,2\% egyéb felsőfokú szakképzés, technikum, 1,2\% doktori fokozat). Érettségit követő szakképzés, középfokú technikum 3,9\%-uk, érettségi 8,1\%-uk legmagasabb iskolai végzettsége volt, szakiskolát, szakmunkásképzőt érettségi nélkül 1,5\%-uk végzett. Felsőfokú szociális végzettséggel a megkérdezettek $72,1 \%$-a rendelkezett. A válaszadók 19,3\%-a volt intézményvezető.

A munkavégzés településének típusa szerint elmondható, hogy a válaszadók 43,6\%-a városban dolgozott, megyei jogú városban vagy megyeszékhelyen $24,9 \%$, községben és a fővárosban is a válaszadók 24,6\%-a dolgozott (több válasz is megjelölhető volt). A válaszadók $33,2 \%$-a a Közép-Magyarországi régióban dolgozott, az Észak-Alföldi régióban 18,1\%, Dél-Alföldön $15,7 \%$, a többi régióból hasonló (10\% körüli) arányban töltötték ki a kérdöívet. A téma szempontjából fontosnak tartottam megkérdezni a munkavégzés helyszínét is, hiszen teljesen más eszközhasználata és igényei lehetnek egy irodában dolgozó szakembernek, egy távmunkában dolgozónak, vagy egy terepen dolgozó munkatársnak. A válaszadók 73,3,\%-a a munkahelyén, a szervezet székhelyén vagy telephelyén, irodájában, 25,8\%-uk a munkaidő nagyobb részében terepen, úton, ellátottak, gondozottak otthonában, $0,9 \%$ pedig az otthonában, távmunkában dolgozik. Ahogy az eredményekből tehát látható minden negyedik szakember a munkaidő nagy részében nem az intézményben dolgozik, hanem terepen van.

\footnotetext{
${ }^{4}$ Az ezzel a módszerrel elérhetetlen szakemberek aránya megbecsülhető, ha abból indulunk ki, hogy az Eurostat adatai szerint 2019-ben a 16-74 év közötti életkorú magyarok 80\%-a internetezett és 69\%-a használta a közösségi médiát (http2, http3) és feltételezem, hogy a szociális ágazatban dolgozók körében is hasonló a közösségi médiát használók aránya, akkor legfeljebb a szociális ágazatban dolgozók legfeljebb 20-30\%-a nem volt elérhető az interneten és a közösségi médián keresztül.

5 2014. szeptemberi adat szerint a fỏállásban képesítési elöírásokhoz kötött tevékenységet végzők 91\%-a nő volt. (Goldmann 2014)
} 
Megvizsgáltam azt is, hogy milyen típusú ellátásban dolgoznak a válaszadók ${ }^{6}$. Sikerült a szociális ágazat legkülönfélébb területein dolgozó szakembereket elérni. Néhány ellátástípusból kiemelkedően sokan válaszoltak, így például a gyermekjóléti ellátásokból, vagy a támogató szolgáltatásokból. Ez abból adódhat, hogy milyen közösségi média felületeken került megosztásra a kutatás felhívása, lásd Függelék 1. táblázat.

\section{Infrastruktúra}

Infrastruktúra, munkahelyi feltételek, eszközhasználat jellemzöi

A munkavégzéshez használt eszközök - a leggyakrabban említettől kezdve - a fénymásoló, a nyomtató, a szkenner, az asztali számítógép, az okostelefon, a projektor, a digitális fényképezőgép. A digitális kamerát, tabletet, webkamerát, okosórát használók száma elenyésző, robotokat és VR technológiát egyáltalán nem használnak ${ }^{7}$.

1. ábra. Munkavégzéshez használt eszközök (\%, N=337, több választ is megjelölhettek)

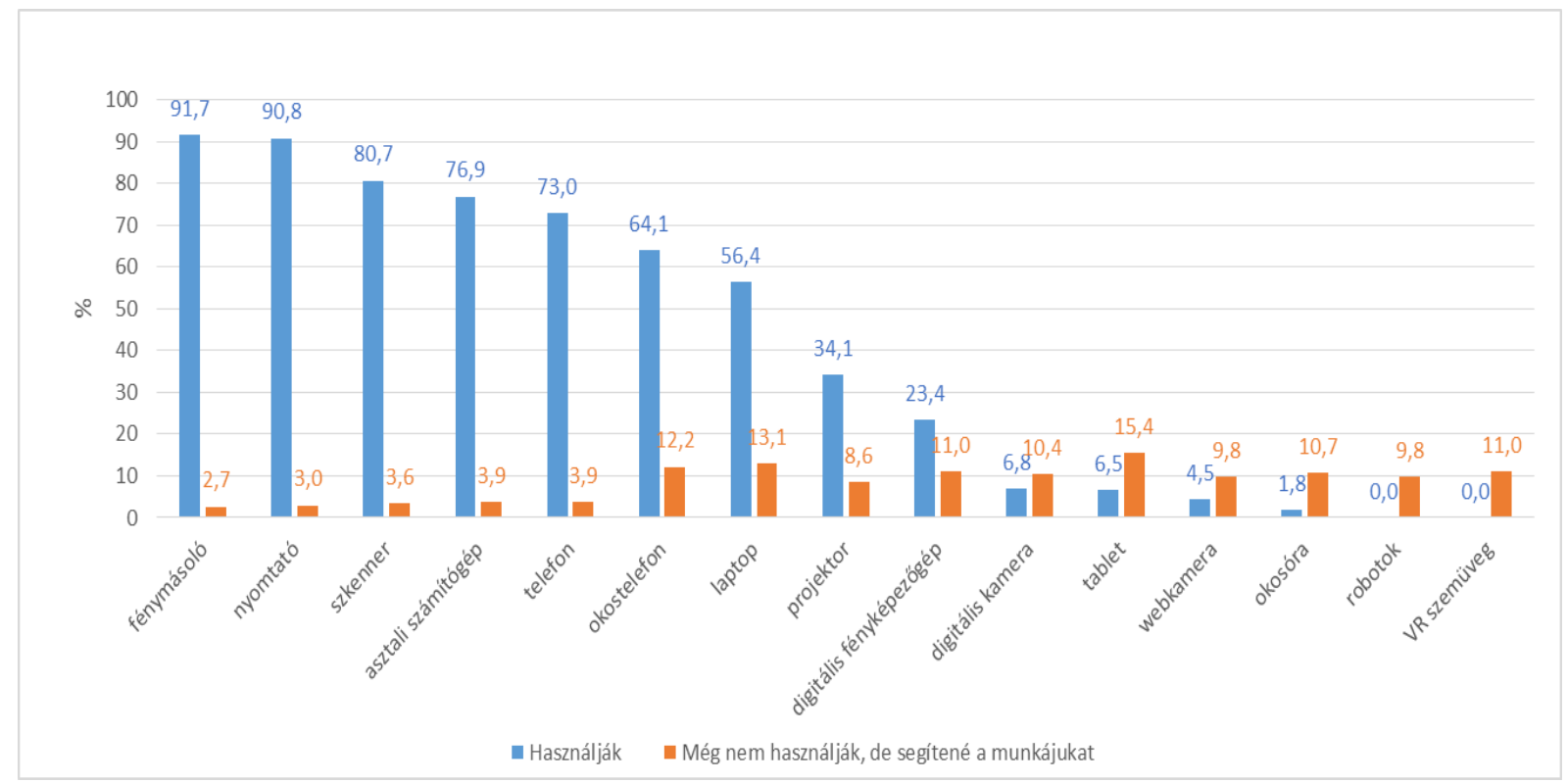

Forrás: saját szerkesztés

6 Több mint 30\%-uk dolgozott család- és gyermekjóléti szolgálat/központnál (30,6\%, 103 fó), házi segítségnyújtásban 12,5\%, jelzőrendszeres házi segítségnyújtásban 3\%, idősek otthonában 12,2\%, időskorúak nappali ellátásában 11\%, fogyatékos személyek nappali ellátásában 7,1\%-uk, szociális konyha/étkeztetésben $5,9 \%$, területi gyermekvédelmi szakszolgáltatásban $6,8 \%$, lakásotthonban $2,4 \%$. Utcai szociális munkát végzett a válaszadók 3\%-a, hajléktalanok átmeneti szállásán dolgozott 3,6\%-uk, nappali melegedőben 4,2\%, éjjeli menedékhelyen 3,6\%, családok átmeneti otthonában 5\%. Támogató szolgáltatásban a válaszadók 10,7\%-a dolgozott, szenvedélybetegek és pszichiátriai betegek nappali és közösségi ellátásában nagyjából 3-3\%. Ezen kívül nagyon sokféle ellátástípusból csak 1-2 fö válaszolt.

7 A világ bizonyos részein a robotok és a VR használata már elterjedt például mentálhigiénés szolgáltatások nyújtásában, prevencióban, gondozási tevékenységek végzésében stb., lásd az irodalomjegyzékben feltüntetett, telemedicina témájú tanulmányomat (Tóth 2017b), ezért kerültek be a válaszlehetőségek közé opcióként. 
A válaszok sorrendjéből jól látszik, hogy a rendszer még mindig nagyon papír alapú. Rákérdeztem arra is, hogy vannak-e olyan eszközök, amit még nem használnak, de lenne rá igényük. Legtöbben a tableteket, laptopokat, okostelefonokat említették, de közel 10\% azoknak az aránya is, akik projektort, webkamerát, fényképezőgépet, digitális kamerát, okosórát, robotokat vagy VR szemüveget használnának.

Az ellátások több, mint 70\%-ában (70,5\%) három évnél idősebb számítógépeket, laptopokat használnak ( $\mathrm{N}=322$, ahol egyáltalán nem használnak számítógépet, ott erre nem válaszoltak). A fejlesztési igényeket felmérő nyitott kérdésre adott válaszok közt nagyon sokan utaltak arra, hogy rossz, régi, nem megfelelően müködő számítógépeken, laptopokon kénytelenek dolgozni, ami nem teszi lehetővé a hatékony munkavégzést.

A megkérdezettek 95\%-a szerint a munkahelyén biztosítják az internet hozzáférést, 5\%-ban nem. Ez az 5\% elsőre nem tünhet magasnak, de ha belegondolunk, hogy milyen sokféle tevékenységhez szükséges ma már az internetkapcsolat, akkor ez is nagyon soknak számít. A válaszadók 84,9\%-a mondta azt, hogy munkahelyén van wifi hálózat (is), ami 95,8\%-ban jelszóval védett $(\mathrm{N}=284)$. Egy nyitott kérdésre adott válaszukban többen felhívták rá a figyelmet, hogy az internet hozzáférés nem csak a dolgozók, hanem az ellátásokat igénybe vevők számára is nagyon fontos lenne, a betérő kliensek vagy az intézményben élö lakók is interneteznének, ez azonban sokszor nem áll rendelkezésre, vagy csak nagyon gyenge minőségben.

Felmértem, hogy van-e olyan informatikai szakember, aki támogatja a szociális dolgozók IKT használatát, aki lehetővé teszi, hogy megfelelően karbantartott, frissített, biztonságos hálózatot és eszközöket használhassanak az intézményekben, akihez tanácsért, segítségért fordulhatnak. A válaszadók szerint az ellátások nagy részében van ilyen szakember, az ellátás telephelyére 33,8\%-ban a fenntartó székhelyéről jár ki a rendszergazda, 31,8\%-ban külső szakember vagy cég látja el a rendszergazdai feladatokat, $14,5 \%$ szerint az ellátás telephelyén állandó alkalmazott a rendszergazda. A megkérdezettek 13,6\%-a válaszolta, hogy náluk egyáltalán nincs rendszergazda, a válaszadók 4,5\%-a pedig nem tudta megmondani van-e. Egyéb választ is megjelölhettek, volt, aki itt jelezte, hogy önkéntes látja el a rendszergazdai feladatokat.

Mivel a szociális intézményekben nagyon sok személyes és szenzitív adatot kezelnek, ezért biztonsággal és adatvédelemmel kapcsolatos kérdéseket is feltettem. A válaszadók $26,4 \%$-a mondta azt, hogy a számítógépeik nem védettek jelszóval, levelezőprogramjában kétlépcsős azonosítást mindössze a megkérdezettek 8,9\%-a alkalmaz ${ }^{8}$. A válaszadók negyede nem választja szét a szakmai és magánjellegü levelezését.

Háromból ketten mondták azt, hogy egy számítógépet többen használnak, illetve a válaszadók több, mint harmada mondta, hogy jellemzö, hogy egy felületet vagy fiókot többen ugyanazzal a felhasználóval és jelszóval használnak. Mindezek nagyon komoly biztonsági, adatvédelmi kockázatokat jelentenek, illetéktelen személyek is hozzáférhetnek adatokhoz, a szakember vagy az intézmény nevében eljárhatnak, aminek súlyos jogi következményei lehetnek. A válaszadók több, mint harmadával előfordult, hogy saját internet előfizetését használta munkájára is, illetve a válaszadók több, mint felével megesett, hogy saját eszközein - laptopján, számítógépén, okostelefonján stb. - is dolgozott. (Egy másik, az eszközök eredetét vizsgáló kérdésre válaszolva $25 \%$-uk mondta, hogy saját eszközön is dolgozik, az a rendszeres használatra vonatkozott.) Ez több szempontból is aggályos, egyrészt nem terhelhető a munkavégzéshez elengedhetetlen eszközök és előfizetések költsége a munkavállalóra, másrészt a saját eszköz használata során gyakran nem biztosított megfelelően az adatvédelem. A saját eszközök

\footnotetext{
${ }^{8} \mathrm{~N}=313$, aki egyáltalán nem e-mailezik erre nem válaszolt. Az alacsony százalék nem adódhat abból, hogy nem tudták mit jelent a kétlépcsős azonosítás, mivel magyarázat is szerepelt a kérdésben.
} 
használata negatívan befolyásolhatja a szolgáltatás minőségét is, mert a fenntartó nem lesz motivált az infrastruktúra fejlesztésében, sem a munkavállalók képzésében.

2. ábra. Az „Elöfordul-e hogy...” kezdetü kérdésre adott válaszok $(\%, \mathrm{~N}=337$, több választ is megjelölhettek)

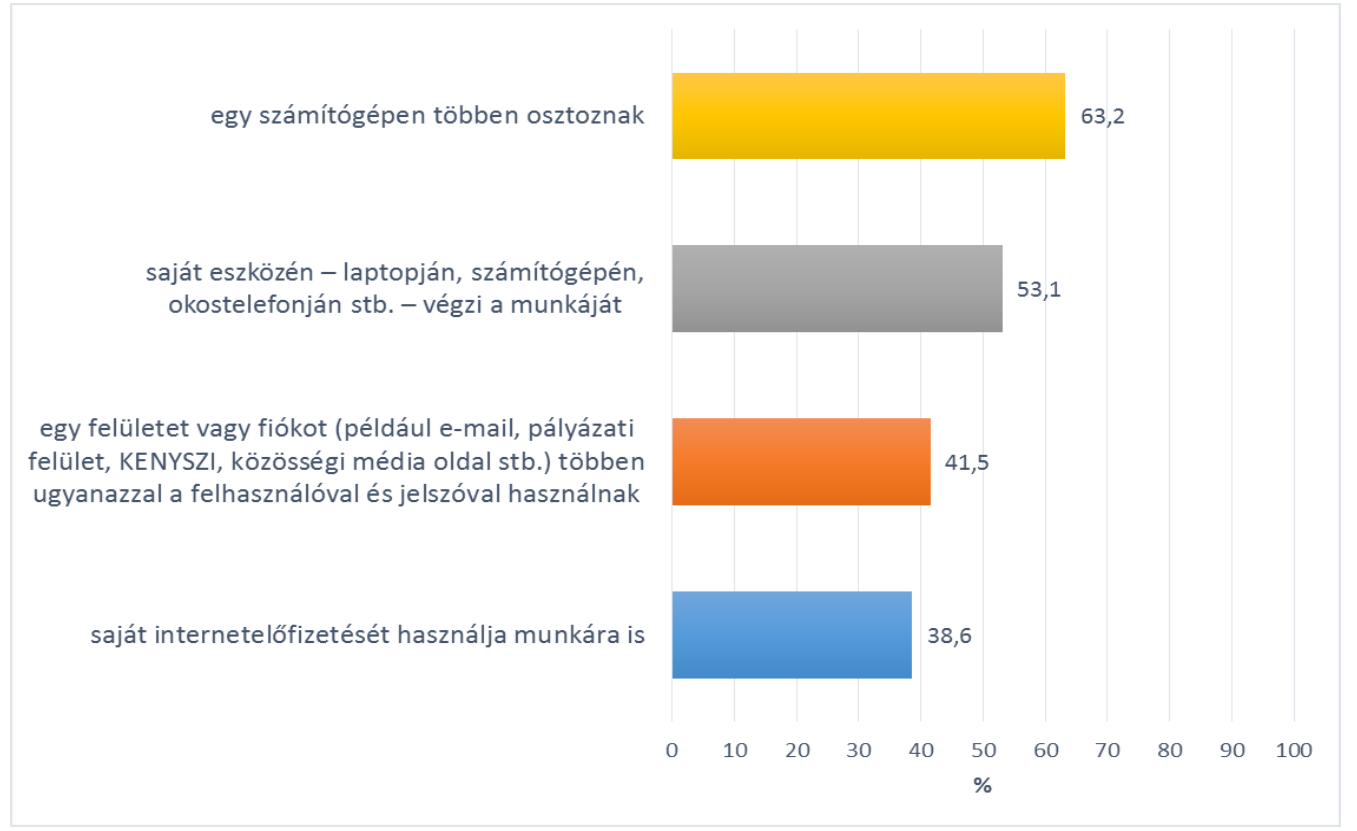

Forrás: saját szerkesztés

A válaszadók $68,8 \%$-a szerint van munkahelyének weboldala, 52,2\%-uk szerint van közösségi oldala. A válaszadók szerint az intézmények honlapját és közösségi oldalát a legtöbb helyen a feladatra kijelölt munkatárs szerkeszti, frissíti (41\%), 27,1\%-ban több munkatárs, 21,5\%-ban a rendszergazda, 18,3\%-ban az intézményvezető, a fenntartó 5,2\%-ban, külsős cég 3,6\%-ban. $(\mathrm{N}=251)$. A weboldalak kapcsán az is fontos lenne, hogy mindenki elérhesse a szociális intézmények oldalán szereplő információkat, a fogyatékossággal élők is, hiszen ők alkotják a szociális ellátások egyik fó célcsoportját. Amennyiben az akadálymentesítés még nem megoldott, akkor a szociális munkások feladata is lenne a fogyatékossággal élő kliensek érdekeinek képviselete, hozzáférésük segítése, a fenntartók figyelmének felhívása a problémára, az akadálymentesítés fontosságára. A megkérdezettek 28,3\%-a szerint akadálymentes az intézményük weboldala, azonban mintegy 36,7\%-uk nem tudta megmondani, hogy az akadálymentes-e $(\mathrm{N}=237)$. Ez a magas arány azt jelzi, hogy sok helyen még nem is gondoltak erre, nem foglalkoztak az akadálymentesítéssel.

\section{Szabályozás}

A megkérdezettek válaszai alapján mindössze az intézmények 38,3\%-ának van elöírása, utasítása a munkatársak technológia használatára, közösségi média használatára, online kommunikációjára vonatkozóan. A válaszadók 69,4\%-a szerint a kliensekkel való online kapcsolattartásra vonatkozóan munkahelyén nincs semmilyen előírás. 12,5\%-uk szerint írásbeli szabályzat, utasítás vagy ajánlás van, 18,1\%-uk mondta azt, hogy szóbeli utasítást kaptak erre vonatkozóan a dolgozók. Nyitott kérdést tettem fel arra vonatkozóan, hogy amennyiben van írásbeli elöírásuk, vagy szóbeli utasításuk a kliensekkel való online kapcsolattartásra 
vonatkozóan, akkor az mit tartalmaz, erre 59 fő válaszolt. Öt nagy csoportba lehet osztani a válaszokat, dőlt betüvel kiemeltem néhány tipikus, igen beszédes választ:

(1) sok helyen tiltják

- „Klienseinkkel való kommunikáció csak hivatalos formában történhet. A közösségi médiában való kommunikáció klienseinkkel tilos."

- „Facebookos kommunikáció tilos, e-mail váltás csak a központi e-mail címröl (kivéve az iskolai szoc. munkásoknak)"

- „Ellátottakkal tilos a kapcsolattartás a közösségi médiában.”

- „A közösségi média az intézményben nem használható. Nincs a közösségi médián az intézmény, mert a hozzászólások és a kezelése egész embert kívánna, sok esetben éjjelnappal, hogy a valós információk kerüljenek fel oda. E-mailen kommunikálunk elektronikus úton az ügyfelekkel."

(2) van, ahol kifejezetten nem tiltják, de kerülendőnek tartják az online kapcsolattartást

- „Tapasztalat alapján az online kapcsolattartást a lehető legminimálisabbra kell redukálni. A személyes találkozást preferáljuk".

- „Nem javasolt, mivel akkor nem csak a munkaidökeretben történik munkavégzés”

- „Abban az esetben engedélyezett, ha más módon nem tudunk kapcsolatot tartani a klienssel, de nem ez a preferált."

- „Ha a levél, vagy megkeresés a közösségi oldalunkon keresztül érkezik, a kapcsolatfelvétel után törekszünk a személyes találkozóra, illetve az személyes megbeszélésre."

(3) van, ahol csak bizonyos módjait támogatják (pl. csak intézményi e-mail címről, de a közösségi médiában nem, vagy kikötik, hogy a kliens nem lehet ismerős a közösségi médiában, felhívják a figyelmet a határok és keretek szigorú megtartására)

- „Engedélyezett a közösségi oldalon való kapcsolattartás, de az intézménnyel kapcsolatos dolgokat, képeket posztolni nem lehet."

- „Gondnokság alatt álló ellátottakról sem fényképet sem hangfelvételt nem készithetünk. Nem tehetjük ki közösségi oldalakra"

- „Ellátott ne legyen ismerös a közösségi médiában”

- „Ha szeretnénk be, illetve visszajelölhetjük a lakókat facebookon, de óvatosan, és válogassuk meg kiket, mert visszaélhetnek ezzel ... másfelöl meg hasznos lehet ...."

- „Csak szervezési kérdésekben lehet ilyen úton egyeztetni (idöpontok, lemondások)”

- „Hivatalos e-mail címröl lehet kommunikálni. Illetve ha elérhetetlen a kliens közösségi oldalon intézményi regisztrációval üzenhetünk."

- „A problémákra szabad csak koncentrálni a klienssel. Politizálni nem szabad! A munkaidön túl nem ajánlott a kapcsolattartás. "

- „Intézmény profiljába tartozó szolgáltatások hirdetésére (pl. Adomány érk. Értesités, csoportok, rendezvényekröl tájékoztatás)"

(4) van, ahol felhívják a dolgozók figyelmét az etikai kódex és a GDPR figyelembe vételére

- „Etikai szabályzat tartalmazza a nem megengedett módozatokat.”

- „GDPR szabályzat tartalmazza, de nem volt ismertetve a dolgozók körében, hogy ez hogyan kell megvalósuljon a mindennapi életben! Ezért a korábbi kommunikációs gyakorlat jellemzö (adhoc módon)!" 
- „Engedélyezett korlátozva az adatvédelem megtartásával”

- „Személyes adatok küldése messengeren tiltott, fotók vagy bármilyen személyes adat közösségi oldalakon tiltott"

(5) néhány munkaadó kifejezetten támogatja az online kapcsolattartást és a közösségi média használatát, például célcsoportjuk sajátosságai miatt.

- „engedélyezett, mert a gyerekkel ez az egyik legjobb kommunikációs mód”

Ahogy tehát az eredményekböl látszik, a válaszadók szerint 10-böl 7 ellátásban, intézményben semmilyen módon nem szabályozott a kliensekkel való online kapcsolattartás. Ahol mégis szabályozzák szóban, vagy írásban az online kapcsolattartást, ott egészen változatos módokon: van, ahol kifejezetten tiltják, van, ahol megtürik és van, ahol támogatják. Nagy tehát a bizonytalanság, a szociális szakemberek általában még intézményi szinten sem kapnak segítséget a kliensekkel való online kapcsolattartással, közösségi média használatával kapcsolatban és a szakmai szervezetek sem fogalmaztak meg ajánlásokat, útmutatókat erre vonatkozóan. Kérdés, hogy mennyire lehet professzionális és etikus az így végzett munka, ki védi meg a kliensek jogait és a szakembereket a potenciálisan felmerülő problémák esetén (jogi következmények, zaklatás, konfliktusok stb.).

\section{IKT jártasság, digitális müveltség}

\section{Készségek, IKT jártasság}

Tevékenységek szerint kértem, hogy osztályozzák készségeiket, mennyire értenek az adott tevékenység végrehajtásához. A legmagabiztosabbak a szociális ágazatban dolgozók a böngészésben, internetezésben, szövegszerkesztésben, táblázatkezelésben, az elektronikus ügyintézésben (4-5 közti átlagok), míg a programozáshoz, weblap és kiadványszerkesztéshez, grafikai programok használatához értenek a legkevesebben (2 alatti átlagok).

A digitális technológia használati készségeiket 5 fokú skálán osztályozták a szakemberek, a legtöbben (47,8\%) és összességében átlagosan is közel jónak ítélték azt meg (átlag 3,63). Életkor szerinti átlagokat tekintve megfigyelhető, hogy az életkor emelkedésével a digitális technológia használati készségek önértékelése fokozatosan csökken: míg például a huszonévesek és a harmincasok kifejezetten jónak érzik készségeiket, addig az 50 év felettiek már csak 3,5-es átlagot adtak maguknak. Az életkor tehát meghatározó tényezőnek tünik. Nem és végzettség szerinti különbség is megfigyelhető, míg a férfiak átlagosan 4-esre, addig a nők csak 3,7-re értékelik digitális technológia használati készségeiket. A középfokú végzettségüek átlagosan 3,2, a felsőfokú végzettségüek 3,8-as értékelést adtak maguknak. 
3. ábra. Digitális technológia használati készségek megítélése átlagosan, életkor szerint (az iskolában szokásos módon 1-5-ig osztályozhatták, $\mathrm{N}=337$ )

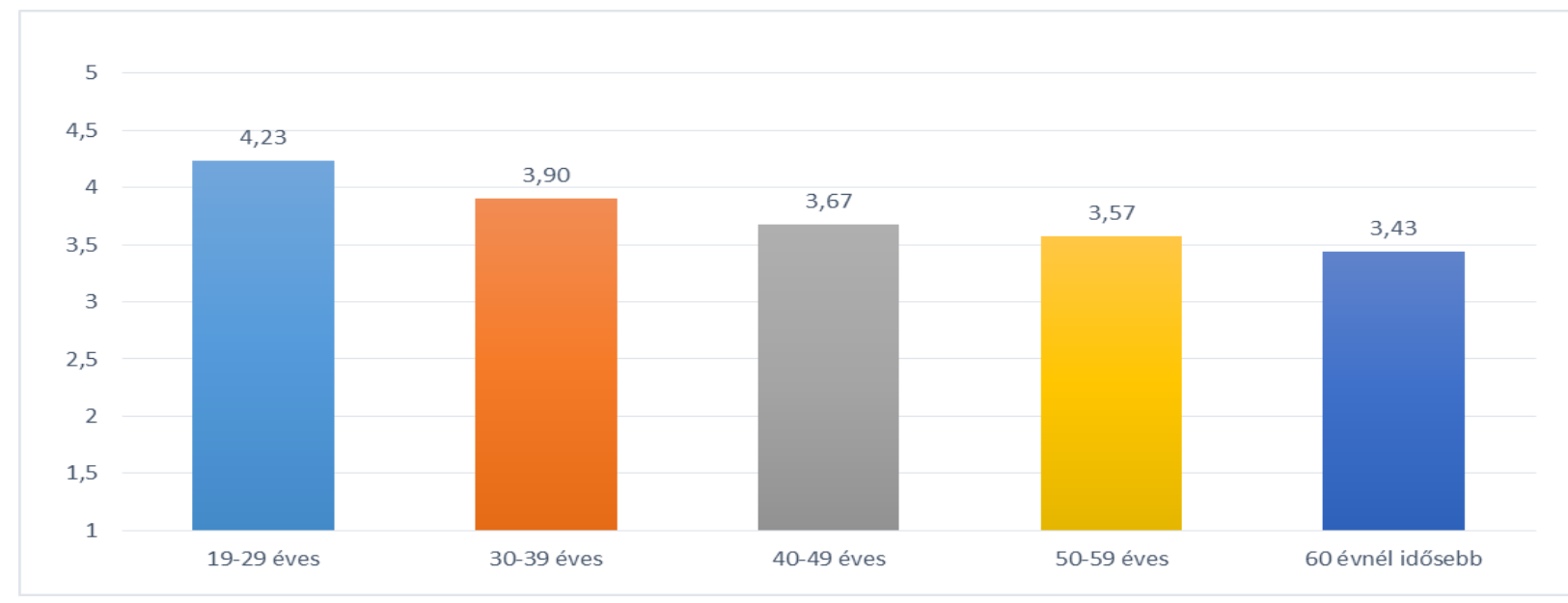

Forrás: saját szerkesztés

\section{Közösségi média használati szokások}

A válaszadók 97\%-a használ közösségi oldalt, szeretném viszont felhívni rá a figyelmet, hogy ebből azonban nem lehet a szociális szakemberek összességére következtetést levonni, hiszen ez a magas arány a mintavétel jellegéből is adódhat. ${ }^{9}$ A közösségi médiahasználati szokásokat önálló kérdésblokkban vizsgáltam, a közösségi médiát nem használó válaszadók ezt a blokkot értelemszerüen nem töltötték ki, átugorhatták a kitöltés során.

A közösségi média használatra vonatkozó kérdésnél a válaszlehetőségek közt a Magyarországon legnépszerübb közösségi oldalakat tüntettem fel ${ }^{10}$ és egyéb opció megadását is lehetővé tettem. A közösségi média használó válaszadók közül a legtöbben Facebookot, Facebook Messengert, YouTube-ot, Vibert, Instagramot és Pinterestet használnak. A kérdésben szétválasztottam a magánemberként és a szakemberként való közösségi média használatot. Az eredmények megerősítették azt a sejtésemet, hogy azokat a felületeket használják szakmai tevékenységek végzésére is a szakemberek, amelyeket magánemberként is használnak, ahol egyébként is otthonosan mozognak. (Mint ahogy a kliensek is azokon a csatornákon keresztül érhetőek el könnyen, illetve ott kérnek segítséget, amelyeket egyébként is használnak.) A Facebook és a Facebook Messenger szakmai és magán célokra való használatnál is vezet. Számítottam rá, hogy a segítők jellemzően nem használják a fiatalok által kedvelt TikTok-ot vagy Snapchatet (pedig ezen célcsoportok eléréséhez, megszólításához jó eszköz lehetne). Ami meglepett, hogy még a szakmai kapcsolatépítésre alkalmas LinkedIn használata sem elterjedt. A vártnál magasabb volt viszont a Pinterest és a Viber szakmai célú használata. Más, nyitott kérdésre adott válaszban kaptam erre magyarázatot, sokan jelezték, hogy a Vibert széles körben használják a kliensekkel való kapcsolattartásra, annak ingyenessége miatt. A Pinterest közösségi képmegosztóval kapcsolatosan saját tapasztalatból kiindulva feltételezem, hogy például foglalkozások, szabadidős tevékenységek megtartásához használhatják. Ehhez hasonló

\footnotetext{
${ }^{9}$ A válaszadók 10,1\% e-mailben, 10,7\%-uk szakmai levelezőlistán, 79,8\%-uk közösségi oldalon/csoportban, 0,4\% egyéb úton - személyesen, fenntartótól, ismerőstől messengeren stb. - kapta meg a kutatás felhívását.

10 A Statista.com 2020. januári nemzetközi rangsorát figyelembe véve, kivéve a csak Ázsiában népszerü platformokat (http5).
} 
célokra, de akár tanulásra, önképzésre, elöadások meghallgatására alkalmas a Youtube, mely szintén népszerünek bizonyult, szakmai jellegü használatra is.

4. ábra. Használt közösségi média felületek, a használat jellege szerint $(\%, \mathrm{~N}=327$, több választ is megjelölhettek, illetve saját választ is megadhattak, az ábrán csak a leggyakoribb válaszok szerepelnek)

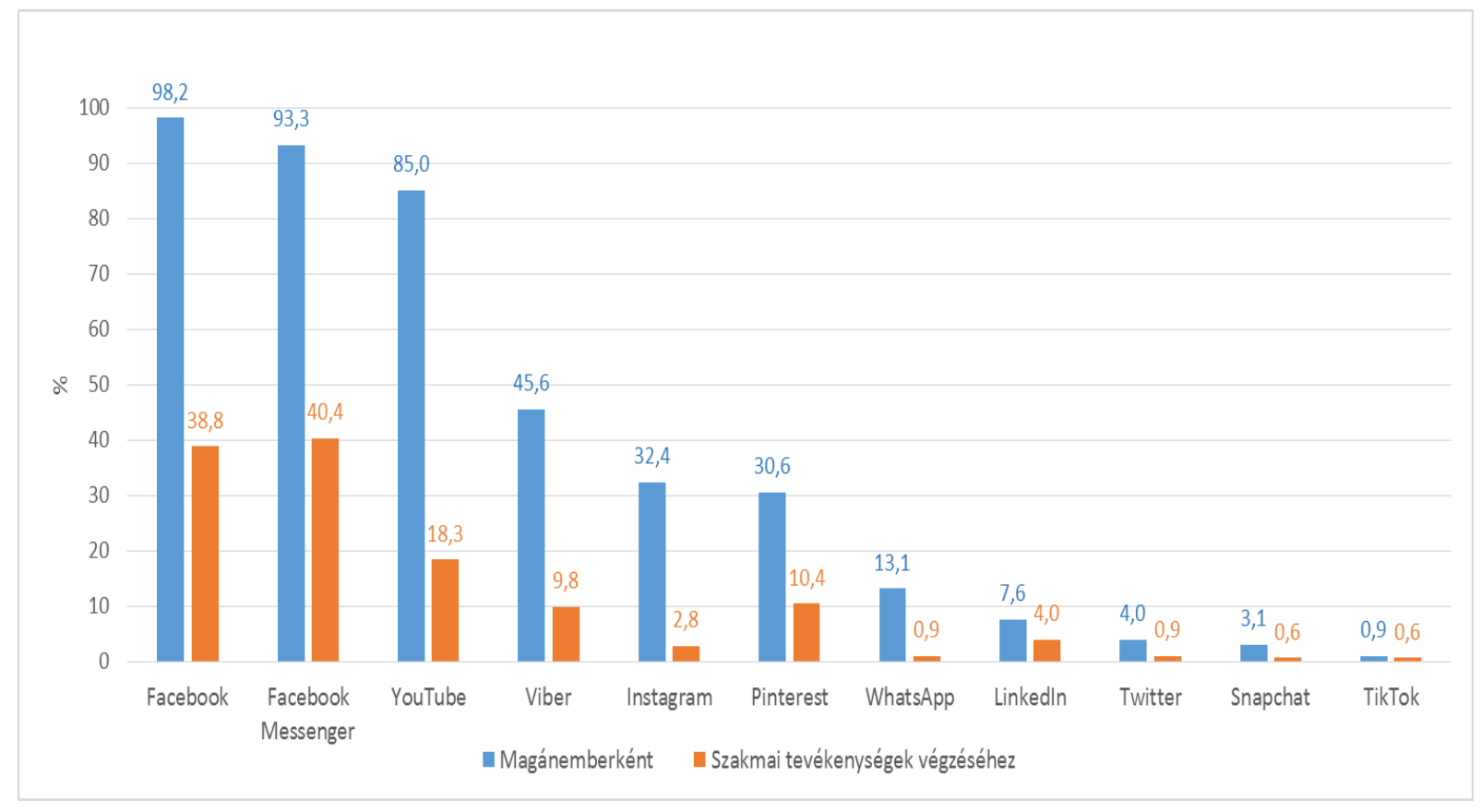

Forrás: saját szerkesztés

A szakemberek 91\%-a követ szakmai szervezeteket, intézményeket közösségi oldalon, tagja szakmai csoportoknak és az is jellemzö, hogy egyszerre több ilyen oldalt is követnek, illetve több csoportnak is tagjai a szakemberek. Azonban az is megfigyelhetö, hogy az IFSW-t vagy egyéb külföldi szakmai szervezeteket mindössze minden tizedik válaszadó követi (feltételezhetően az idegen nyelvtudás hiánya miatt, de erre vonatkozó kérdést nem tettem fel).

A digitális technológia használata szakmai kapcsolatok ápolására, tanulásra, kutatásra, önfejlesztésre

A technológia használata a szakmai kapcsolatok ápolására, tanulásra, önfejlesztésre szintén nagyon elterjedt. Kollégákkal való online kapcsolattartásra a válaszadók 91,9\%-a, tanulásra, továbbképzésre, önképzésre 88,9\%-a, szakmai hírek követésére 83,4\%-a, szakirodalom tanulmányozására 82,2\%-a, szakmai fórumokon és csoportokban tapasztalat és tudás megosztásra 69,6\%-a használja a digitális technológiát. 
5. ábra. A digitális technológia használata szakmai kapcsolatok ápolására, tanulásra, kutatásra, önfejlesztésre $(\%, \mathrm{~N}=332$, több választ is megjelölhettek)

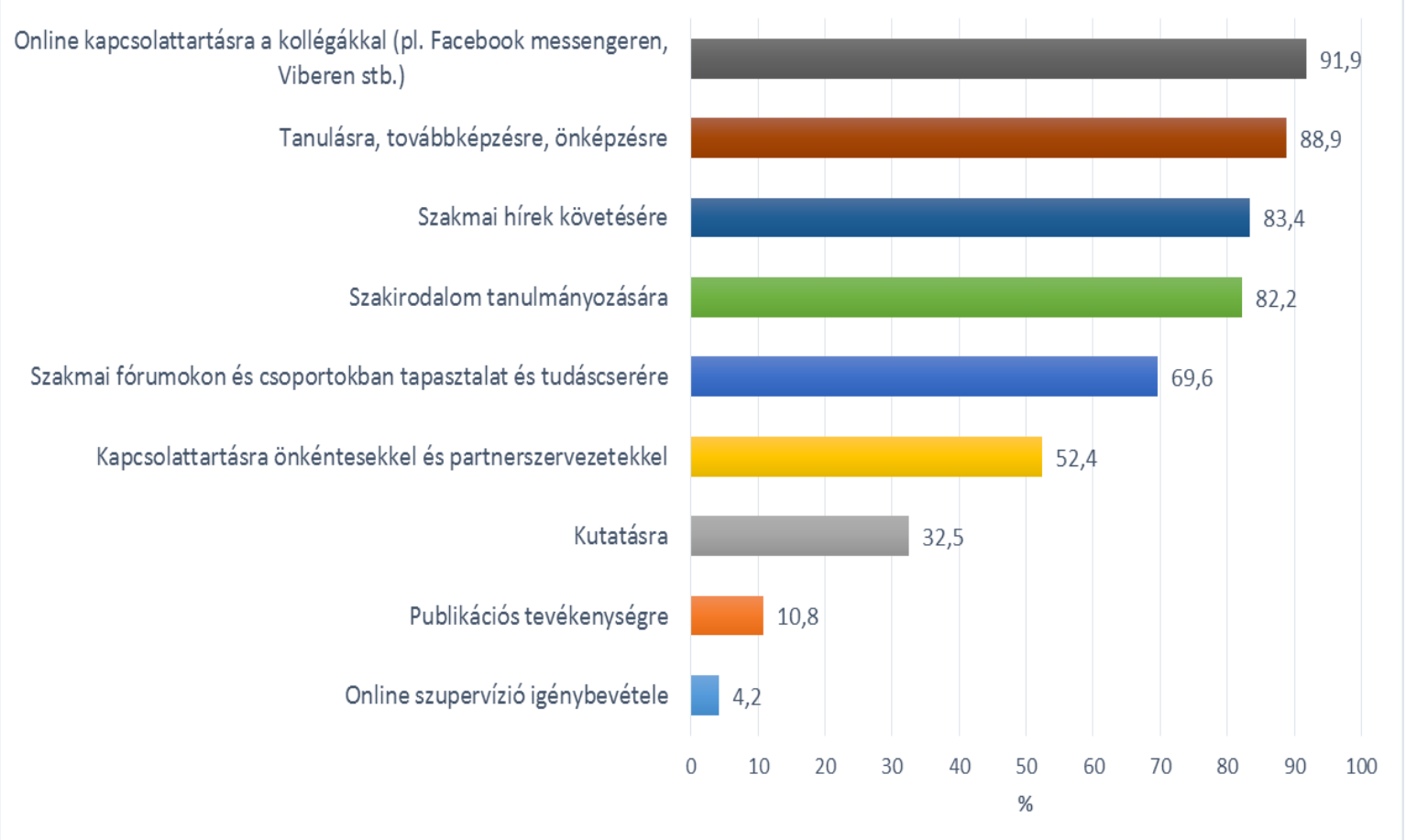

Forrás: saját szerkesztés

\section{Képzettség}

Informatikai, digitális kompetencia fejlesztő képzésen a válaszadók 71,5\%-a soha nem vett részt. Akik részt vett ilyen képzésen többnyire hasznosnak itélték meg a képzést, úgy látják segítette a hatékonyabb munkavégzésüket.

A felsőfokú végzettségü válaszadók $(\mathrm{N}=256)$ több, mint 70\%-a úgy ítéli meg, hogy az egyetemen, főiskolán, felsőfokú tanulmányai során nem kapott megfelelő felkészítést az infokommunikációs technológiák használatára vonatkozóan. Reméltem, hogy a nagyon rossz arányt az okozhatja, hogy az idősebb válaszadók több évtizeddel ezelőtt vettek részt a képzésben, amikor még nem volt nagy hangsúly az egyetemi, föiskolai képzésben az IKT használaton. Ezért megvizsgáltam, hogy a huszonéves és a harmincas felsőfokú végzettségü válaszadók mit válaszoltak erre a kérdésre, azonban azt az eredményt kaptam, hogy a fiatalabbak sem elégedettebbek, az átlaghoz közeli, sőt azt kicsit meghaladó mértékben elégedetlenek a felsőoktatással. A 19-29 év közötti életkorú válaszadók 78,9\%-a, a 30-39 évesek 71,6\%-a érzi úgy, hogy nem kapott megfelelő felkészítést az infokommunikációs technológiák használatára. Ez fontos visszajelzés lehet a felsőoktatás és a szakképzések alakítói számára, sokkal nagyobb hangsúlyt kellene a képzésben fektetni a digitális írástudás és müveltség fejlesztésére. 


\section{A digitális technológia használata a szociális munkában és a gondozásban}

\section{Digitális technológia bevonásával végzett szociális munka}

Az eredmények szerint a kliensekkel, ellátottakkal folytatott munkában igen elterjedt az internet és a digitális technológia használata. A válaszadók 69,4\%-a használja a kliensek számára ügyintézésre, 69,1\%-a az ellátáshoz kapcsolódó kötelező adminisztráció vezetésére, 60,6\%-a a KENYSZI-TEVADMIN rendszer kezelésére, 57,3\%-a a munkához kapcsolódó anyaggyüjtésre, illetve online tartalmak elérésére is 57,3\%-uk. E-mailes kapcsolattartásra az ellátottakkal 45,2\%-uk, online kapcsolattartásra az ellátottakkal 41,8\%-uk, online közösség, csoport müködtetésére 10\%-uk, online konzultációra 8,8\%-uk használja. Minden negyedik segítő használja a digitális technológiát érdekképviseletre, közösségfejlesztésre is.

6. ábra. Digitális technológia használata a gondozásban, a kliensek ellátásában $(\%, \mathrm{~N}=330$, több választ is megjelölhettek)

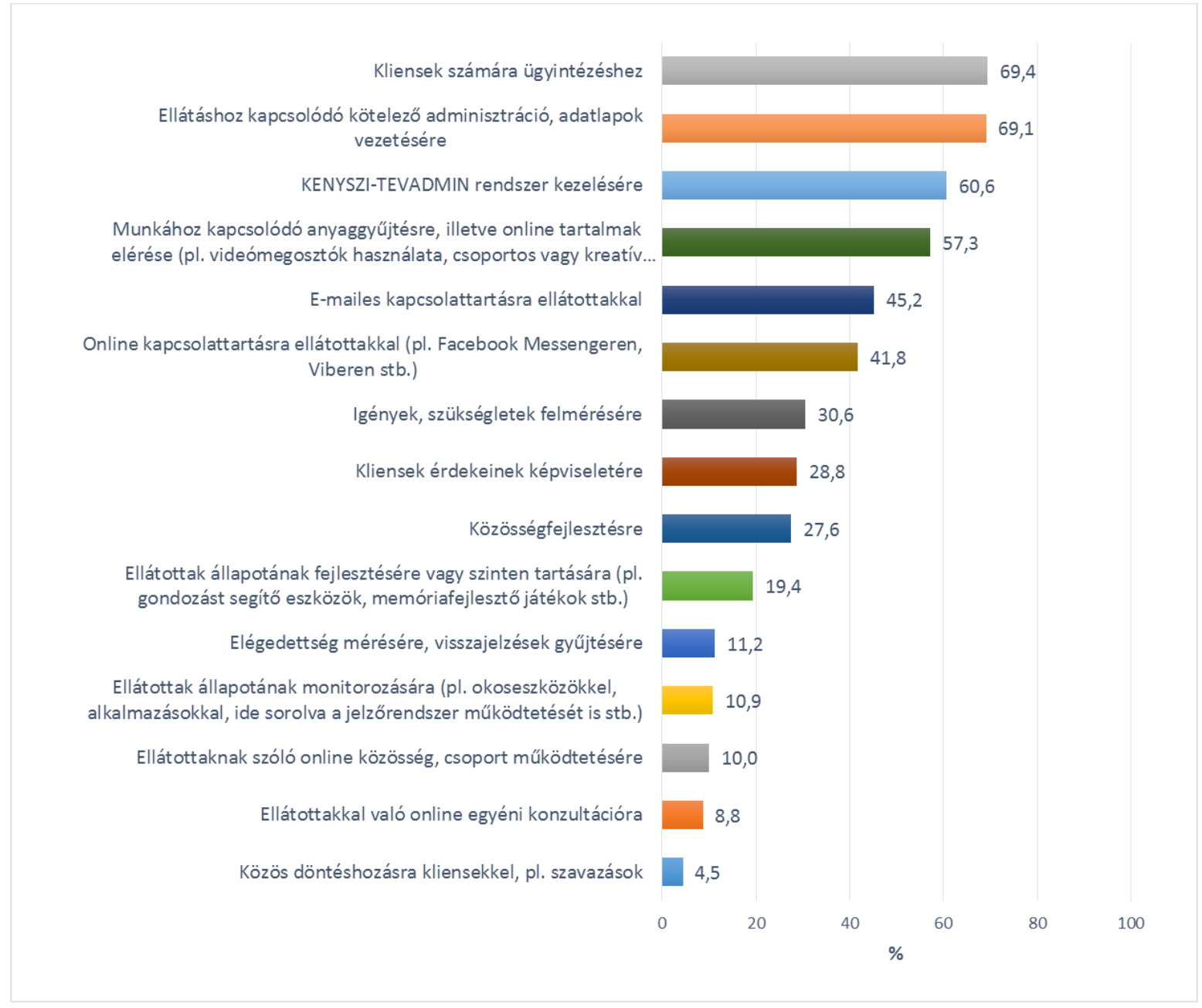

Forrás: saját szerkesztés

Események, rendezvények hirdetésére a válaszadók 63,9\%-a, közösségi oldal működtetésére 47\%-a, szolgáltatások hirdetésére 40,4\%-a, a nyilvánosság biztosítására, levelezőlista müködtetésére, hírlevél küldésére több, mint 37\%-a, adománygyüjtésre 31,7\%-a használja az internetet. Szakmai érdekképviseletre a megkérdezettek 12,2\%-a, szakmai blog írására 4,8\%-a, 
a közvélemény formálására, ellátottak helyzetének bemutatására, érdekeik képviseletére 23\%a, médiakampányokhoz 7\%-uk használja a digitális technológiát.

\section{Kliensekkel való kapcsolat a közösségi médiában}

A segítők úgy gondolják, hogy a kliensek nagy részének (43\%) van igénye a velük, vagy az ellátásukkal való online kapcsolattartásra (közösségi médiában, messengeren, chaten), 30,3\% nem tudta ezt megítélni és csak 26,4\% mondta azt, hogy szerinte nem lenne erre a klienseknek igénye. Ugyanakkor a válaszadók szerint ritkán fordul elő, hogy a kliensek vagy hozzátartozóik az interneten találják meg az ellátásokat és ezáltal kerülnek kapcsolatba. 13,4\%-uk válaszolta, hogy havi rendszerességgel, 5,3\%-uk, hogy heti szinten, 2,7\%-uk, hogy napi szinten fordul ez elö, 34,1\%-uk szerint egyáltalán nem jellemző, a válaszadók 44,5\%-a szerint pedig ritkán.

A kliensekkel való online kapcsolat további vizsgálatához Kolmes és Taube 2013-as kutatása jelentett kiindulópontot (Kolmes - Taube 2014, lásd bővebben az elméleti háttér címü fejezetben), kutatásomban kérdéseik egy részét, némiképp kiegészítve én is feltettem. Az eredmények szerint - 2020-ban, Magyarországon, a szociális ágazatban dolgozó segítők körében - igen magas volt a kliensekre való véletlen és a szándékos keresések és információszerzések aránya. A válaszadók 64,7\%-ával előfordult már, hogy az interneten találkozott véletlenül a kliense adataival, blogjával, vagy profiljával. 57,9\%-uk keresett már rá az interneten kliensére. Közülük legtöbben azt mondták, hogy ez nem befolyásolta a segítő kapcsolatot (azok közül, akik rákerestek már kliensükre, kevesebb, mint 20\%-uk mondta azt, hogy befolyásolta). Érdekes, hogy mégis kétszer annyian voltak azok, akik nem mondták el kliensüknek, hogy rákerestek az interneten, mint azok, akik elmondták ezt. Rákérdeztem a helyzet fordítottjára is: vajon milyen gyakran fordul elö, hogy a kliens keres vagy talál véletlenül a segítőről információkat a neten, a közösségi médiában? Minden ötödik segítő számolt be arról, hogy előfordult, hogy kliense személyes információkat tudott meg róla. Persze valójában ennél sokkal gyakrabban fordulhat ez elő, ezek csak azok az esetek, amelyekről a segítő tudomást szerzett.

7. ábra. Az „Előfordult, hogy kliense ismerősnek jelölte Önt közösségi oldalon?” kérdésre adott válaszok $(\mathrm{N}=325)$

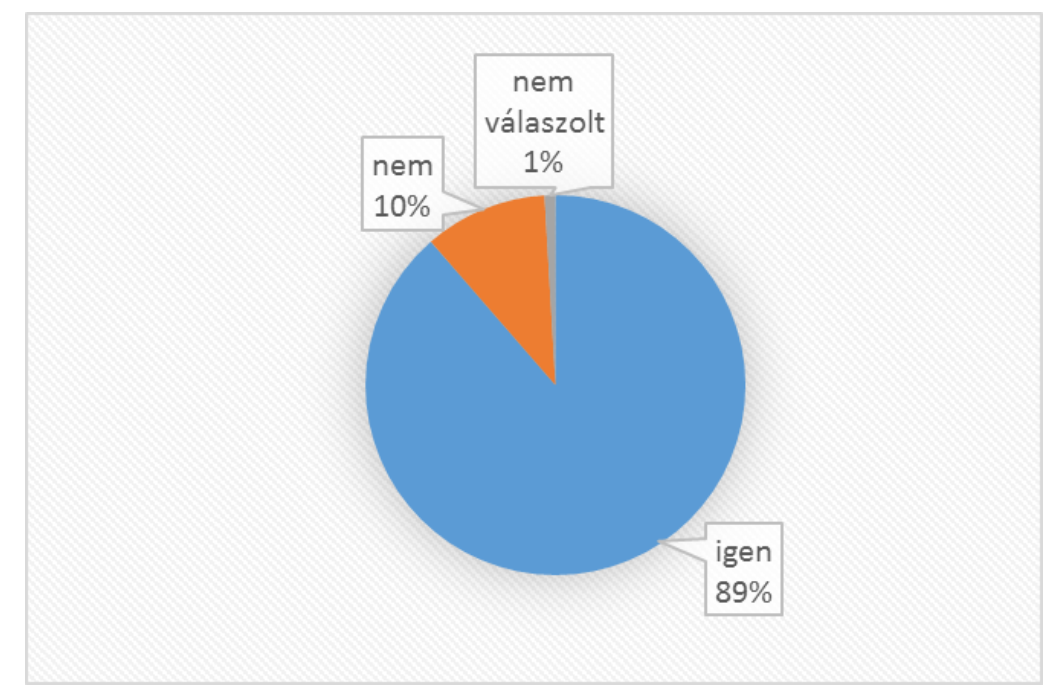

Forrás: saját szerkesztés 
A közösségi oldalt használó válaszadók 88,6\%-ával elöfordult már, hogy kliense ismerősnek jelölte a közösségi oldalon. Vannak, akik elutasítják az ilyen felkéréseket, mert határátlépésnek és személyes kapcsolatnak tartanák, ha a közösségi oldalon is ismerösök lennének a kliensükkel, kutatásom eredményei szerint 10-ből 4 szakember soha nem fogadja el a közösségi médiában az ismerősnek jelölést. Mások nem akarják megsérteni a klienst, ezért felveszik kapcsolati listájukra. A válaszadók 15\%-a mindig visszajelöli a kliens ismerősnek jelölését. 10ből 4-en mérlegelik, hogy melyik kliens jelölését igazolják vissza. Az elővigyázatosabbak alaposan ellenőrzik a biztonsági beállításokat, listákat hoznak létre, és a kliens hozzáférését a személyes tartalmakhoz így próbálják limitálni. A segítők 56,7\%-a válaszolta azt, hogy fokozottan odafigyel a beállításokra, ellenőrzi, hogy mit kivel oszt meg, 35,2\%-uk mondta, hogy magánéletéröl, családjáról soha nem oszt meg semmit a közösségi oldalon.

8. ábra. Közösségi média használati szokások jellemzői, tudatosság (\%, N=321, több választ is megjelölhettek)

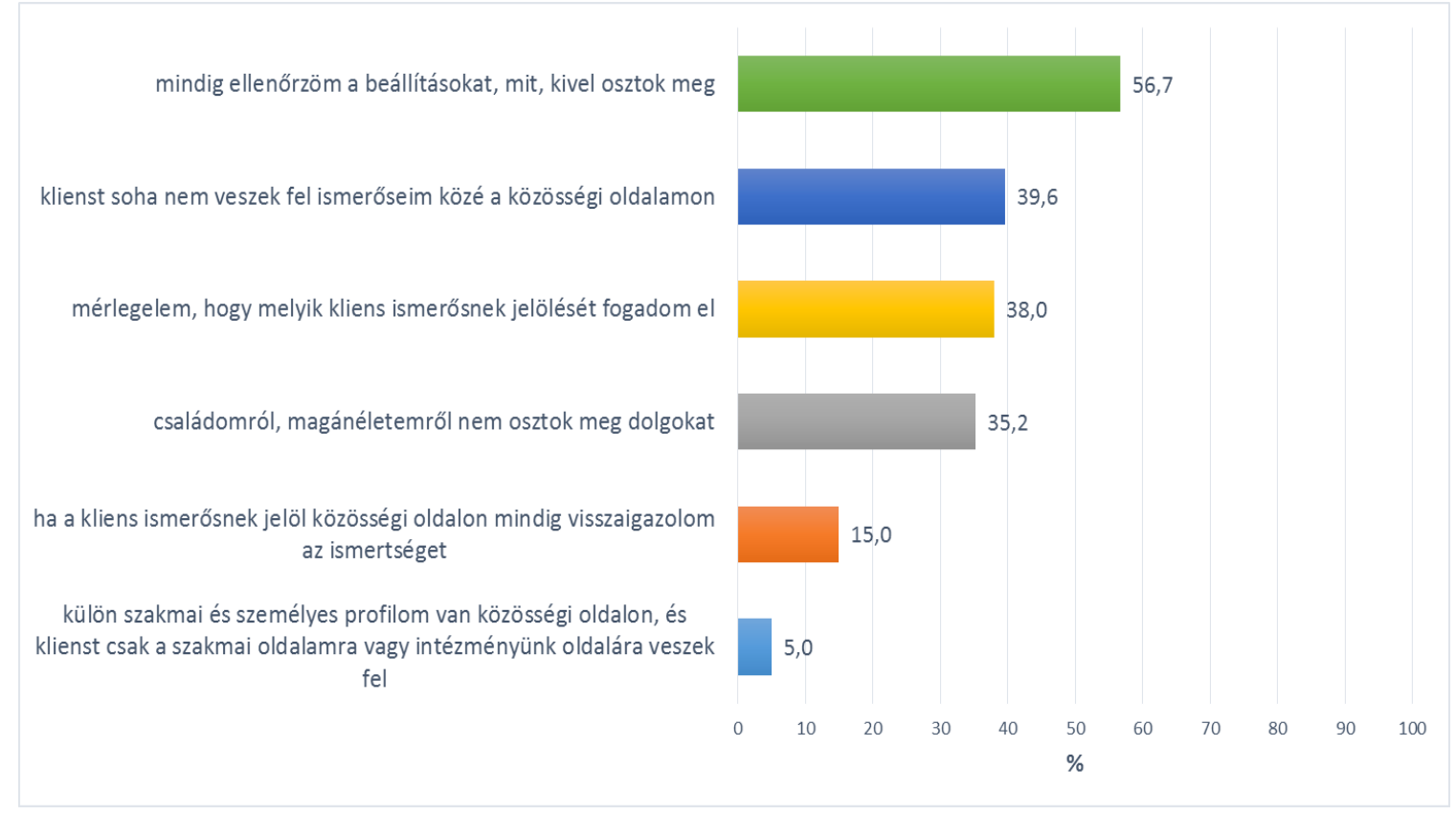

Forrás: saját szerkesztés

Ahogy látszik, nagyon sokféleképpen reagálunk ilyen helyzetekben, gyakran bizonytalanná válunk, nem tudjuk, hogy mi számítana megfelelö viselkedésnek ${ }^{11}$. Az internet közegeiben mozogva úgy tünik, könnyebben elmosódnak a határok, nem feltétlen cselekszünk tudatosan, nem mindig érezzük a tetteink súlyát, jelentőségét, nem azonosítjuk a potenciális veszélyeket. Pedig a közösségi média nem tudatos használatából adódóan pedig számos veszély adódhat, például a kutatásom eredményei szerint a válaszadók 28,7\%-ával előfordult már, hogy a kliense megzavarta a közösségi médiában a magánszféráját $(\mathrm{N}=324)$ és $22,7 \%$ válaszolta azt, hogy volt már szükség arra, hogy letiltsa közösségi oldaláról kliensét vagy törölje ismerősei közül.

${ }^{11}$ Bár a szakmai etikai kódex egyértelműen kimondja, hogy „A kliens és a szociális munkás együttműködése olyan formális kapcsolat keretében valósul meg, amely a bizalmon, az őszinteségen és a kliens autonómiájának tiszteletben tartásán alapul. [...] A szociális munkában összeférhetetlen a szociális munkás és a kliens közötti [...] magánjellegü virtuális érintkezés.” (3SZ Etikai kódex 20. és 23. pont). 
$(\mathrm{N}=322)$. A segítők tanácstalanságát és a határok meghúzásának nehézségét jól jelző egyik válasz ez volt:

„,... a kliensek, akiknek nincs pénzük telefonálni - de szinte mind rendelkezik internettel -, ingyenes lehetöségeket kerestek elérésünkre. A nyári szabadságom alatti facebook zaklatások már olyan messzire mentek, hogy azon voltam, akkor felmondok. Ezek miatt nem telepítettem a messengert, így ha hívnak "csak" a facebookom postafiókja jelzi. De hogy néz az ki - helyi lakosként -, hogy bárkit is kizárjak az ismeröseim közül azon az alapon, hogy kapcsolata van a családsegitövel?!"

Csak minden ötödik válaszadó mondta, hogy van külön szakmai és személyes profilja vagy oldala a közösségi médiában, pedig a szakmai és magánjellegű kommunikáció szétválasztása, a tudatosabb online jelenlét talán egy lehetőség lenne a hasonló problémák megelözésére, a határátlépések elkerülésére.

A közösségi média használat előnyeiröl a megkérdezettek 34,8\%-a számolt be, ennyien mondták, hogy volt pozitív hozadéka annak, hogy a kliensükkel a közösségi médiában tartották a kapcsolatot. $(\mathrm{N}=296)$ Ilyen pozitív hozadékok közt említették meg az alábbiakat:

(1) Lehetőséget teremt a gyors információ cserére, könnyebb és rugalmasabb elérhetőségre, kapcsolattartásra, időpont egyeztetésre, lemondásra. Ez különösen fontos például azoknak, akik több településen dolgoznak, a nap nagy részében terepen vagy úton vannak. Többen említették azt is, hogy a kliensek gyakori telefonszám cseréje miatt ezt biztosabb elérési módnak látják, illetve, hogy vannak, akiknek nincs is telefonos elérhetőségük, viszont a közösségi oldalt használják és azon keresztül elérhetőek.

(2) Több válaszadó említette a gyorsaság mellett az ingyenes kommunikáció lehetőségének fontosságát, ami nem elsősorban a segítő szempontjából fontos, hanem a klienseknek nagy segítség, mivel gyakori, hogy nincs pénz a telefonjukon, de például Viberen így is elérhetőek.

- „Gyors elérhetöség, akár azonnali visszajelzés így egyszerübb az együttmüködés, mivel sokszor nincs sim kártyája a kliensnek."

- „Ott mindig elérhetöek, nem kerül pénzbe sem nekik sem nekem a telefon és azonnal reagálnak. Gyakran változnak a telefonszámok, sok esetben nincsen pénz a kártyájukon telefonálni."

- „Viber használatával elérhetö, válaszra képes az a kliens is, akinek nincs módja telefonhívást kezdeményezni."

- „Sok ügyfél már csak a messengert használja, mert nem jár külön díjjal”,

(3) Krízishelyzet kezelésére, azonnali reagálásra alkalmasnak látják, például volt, aki arról számolt be, hogy eltünt személyt sikerült felkutatni a rendörség segítségével a közösségi médiában, volt, hogy bántalmazási eset derült így ki, volt, aki szökés esetén messengeren érte el a klienst, vagy kutatta fel ismeretségi körén keresztül, vagy krízishelyzetben ennek köszönhetően tudott azonnali segítséget nyújtani.

(4) Használják ügyintézésre, gondozásra, álláskeresés segítésére, elfelejtett intéznivaló megbeszélésére, többen említették, hogy bevásárlólista megosztására, bevásárlással kapcsolatos egyeztetésre használják.

(5) Utánkövetésre is hasznosnak bizonyul, a régebbi kliensekkel a közösségi médiában tartják a kapcsolatot, visszajelzést kap a segítő, megköszönik a munkáját, fáradozásait, látja munkája pozitív eredményét, beszámolnak a korábban közösen meghatározott célok és lépések teljesüléséről, életük alakulásáról. 
(6) Többen úgy érzik, hogy a közösségi médiának köszönhetően erösödik a személyes kapcsolat, voltak, akik szerint erősíti a bizalmi kapcsolatot, van, aki szerint a gesztus számít, hogy visszaigazolja a klienst, van, aki arról számolt be, hogy az online kapcsolattól a kliens hozzáállása pozitívabb lett segítővel és az intézményi szolgáltatásokkal kapcsolatban.

(7) Hallgatókkal való kapcsolattartásra, információ megosztásra is használják.

(8) Segíti a fogyatékossággal élő kliensek, mozgássérültek ellátását, gondozását.

(9) Sok helyzetben hasznos lehet a szöveg visszakereshetősége, az írásbeliség, a lehetőség mindkét fél számára az üzenet alkalmas időpontban történő elolvasására, megválaszolására.

(10) A fiatalokkal könnyebb ezen az úton kapcsolatot tartani, bizalmasan beszélgetni.

(11) Adományokat gyüjtenek a közösségi médiában.

(12) A szakmai tartalmú, közérthető tartalmak megosztása később a személyes beszélgetések során téma lehet, segíthet a kliensnek problémája megfogalmazásában, felismerésében-

(13) A kliens lelki állapotának felmérésére, „háttér információk” megtudására is használják, a közösségi média aktivitásnak - posztolás, képmegosztás - köszönhetően értesülnek a családi eseményekröl, gyermekkel kapcsolatos információkról, a hozzátartozókkal való kapcsolatnak köszönhetően nyernek új információkat.

- „Messengeren írt, hogy segitséget tudjon kérni valamilyen elakadásban.”

- „Megismerjük milyen pszichés állapotban van éppen. Szerelmi bánat, negatív gondolatok stb."

- „Kliens lelki állapotával kapcsolatos információ (nem online lereagált) tudomásul vétele, felhasználása a mentálhigiénés gondozás során."

- „Tudom követni a változásokat az idővonalon történt megosztásaik révén

- „Friss képek a gyermekröl.”

- „Hozzátartozójával való kapcsolat új információkhoz juttatott”

Ezek közül sok megoldás nagyon praktikus, sok esetben a kliensek igényeihez illeszkedö, rugalmasabb ellátást tesz lehetővé, de olyanok is vannak, amelyek etikailag nagyon aggályosnak tünnek, a kliensek vagy a segítők védelme szempontjából lehetnek károsak. Úgy gondolom, hogy nagy szükség lenne arra, hogy a szakmai szervezetek ajánlásokat fogalmazzanak meg a szociális szakemberek közösségi média használatára vonatkozóan, szülessenek ezzel kapcsolatos állásfoglalások. Nagyon fontos lenne a közösségi média használata során felmerülö szakmai és etikai kérdések vizsgálata, a szakemberek tudatos médiahasználatának támogatása, figyelmük felhívása a potenciális veszélyekre, a jó megoldások terjesztése.

\section{Attitüdök és igények}

\section{Attitüdök}

A válaszadók attitüdjeinek vizsgálatához a technológiával kapcsolatos pozitív és negatív állításokat fogalmaztam meg (az elméleti keretek címú részben ismertetett tanulmányok alapján), kértem a segítőket, hogy az iskolában szokásos módon, 1-5-ig osztályozzák mennyire értenek egyet azokkal. Összességében elmondható, hogy alapvetően pozitívan viszonyulnak a technológia használathoz, érdeklik őket a technológiai újítások, innovációk, szívesen próbálnák ki azokat. Úgy látják, hogy a technológia használata megkönnyítheti a gondozást, 
kapcsolattartást, nagy előnyének tartják, hogy a technológia segítségével olyan célcsoportokat is elérhetünk, amelyeket korábban nem, vagy csak nehezen. Kiváló eszköznek tartják a közösségi médiát a gyors tudásmegosztásra, tanulásra, önfejlesztésre. A legtöbben egyetértenek azzal, hogy a virtuális térben folytatott párbeszéd elösegíti a szakmai érdekek széles körü érvényesítését. Néhány kérdésnél középre húztak, nem foglaltak állást, ilyen volt a technológia használat veszélyessége, hogy etikai szempontból aggályosnak tartják-e a használatát ${ }^{12}$, vagy a saját felkészültségük megítélése és a munkahelyi feltételek megléte.

9. ábra. Technológia és közösségi média használattal kapcsolatos attitüdök (osztályozták az iskolában szokásos módon, hogy mennyire értenek egyet az állításokkal)

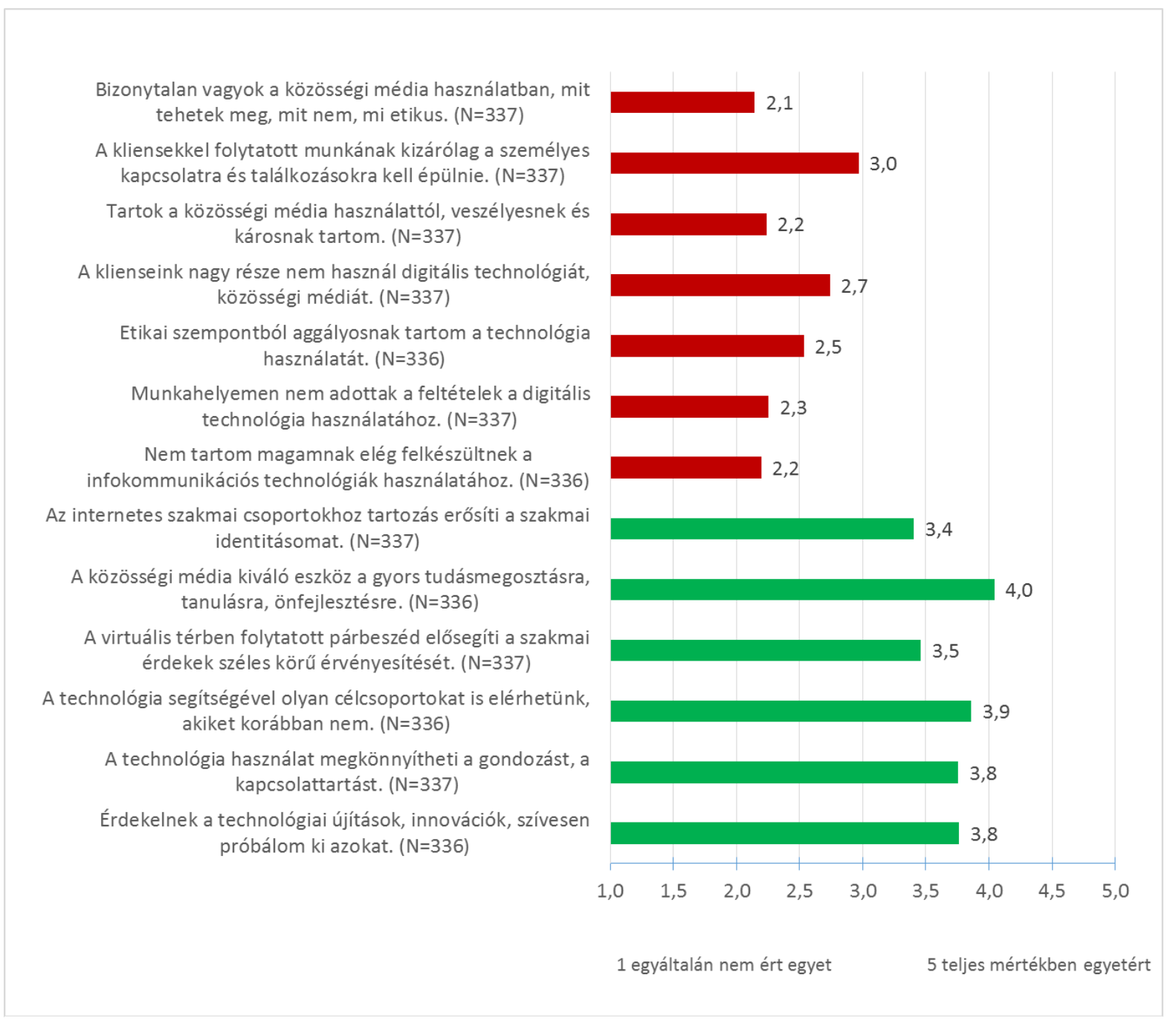

Forrás: saját szerkesztés

\footnotetext{
${ }^{12}$ Ez az eredmény arra is utalhat, hogy bizonytalanok ebben a témában, lásd Ternay Andrea 2017-es publikációját, melyben felhívja rá a figyelmet, hogy vannak, akik nem ismerik az etikai kódexet, nem biztosak abban, hogy mi etikus és mi nem, nem ismerik fel a dilemmákat, szükséges lenne a szociális munkások etikai oktatását is fejleszteni (Ternay 2017). Úgy gondolom, hogy ez valóban fontos lenne és az IKT-használatból eredő etikai kérdésekre és etikai dilemmákra is ki kell térni.
} 
A válaszadók attitűdjei a digitális technológia és közösségi média használattal kapcsolatosan tehát többnyire pozitívak, annak ellenére, hogy a kliensekkel való online kapcsolat fejezetben bemutatott eredmények szerint számos negatív tapasztalatuk is van. Internetes zaklatást általánosságban, nem a kliensek felöl - minden ötödik (19\%) válaszadó tapasztalt már.

\section{Igények}

A megkérdezett szociális szakembereknek nagy igénye van új eszközök, programok beszerzésének támogatására $(69,4 \%)$, a szociális munkások közösségi média használatára vonatkozó szakmai, módszertani útmutatóra, ajánlásra $(58,8 \%)$, hozzáférésre az ellátórendszerre vonatkozó friss adatbázisokhoz $(58,5 \%)$ és informatikai képzésre munkatársaiknak $(55,5 \%)$.

10. ábra. Az alábbiakra lenne igénye a válaszadóknak $(\%, \mathrm{~N}=337$, több választ is megjelölhettek)

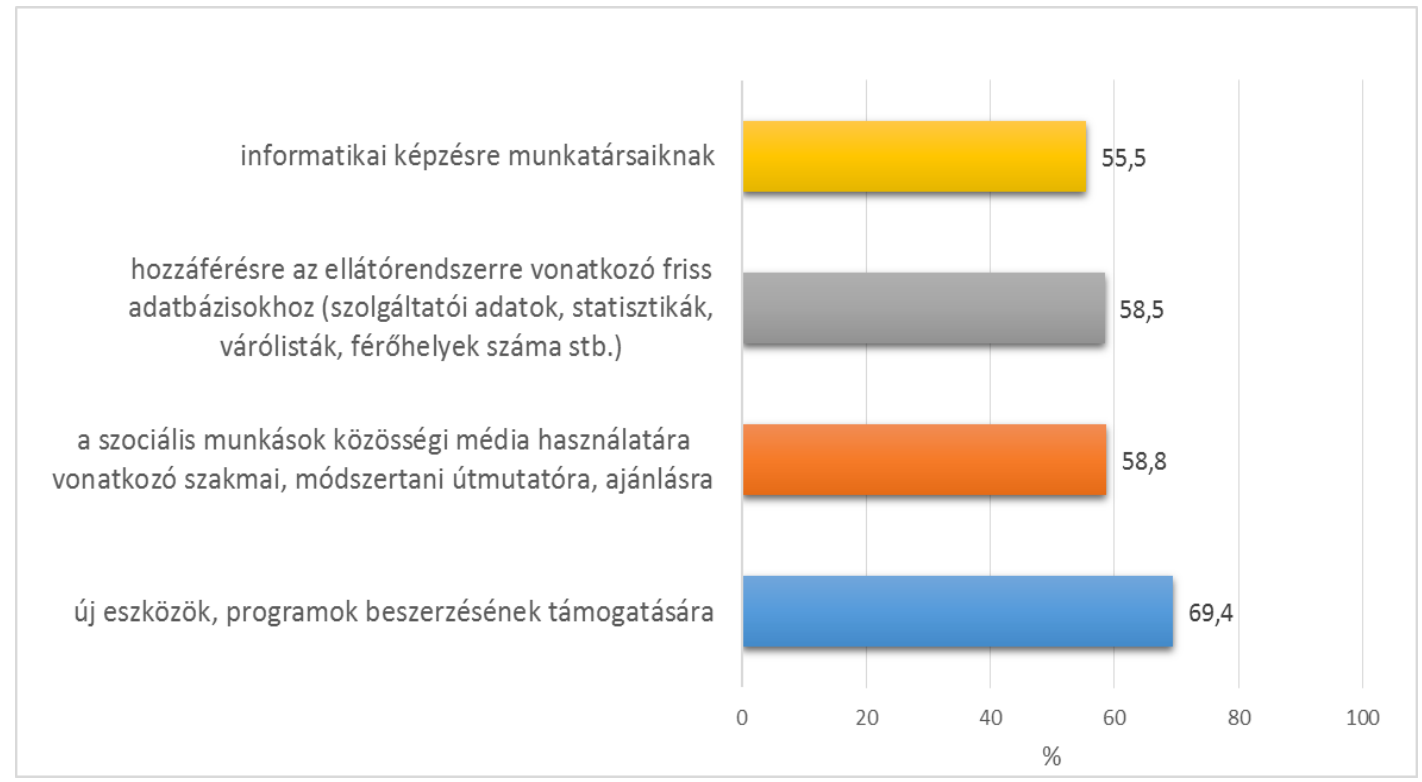

Forrás: saját szerkesztés

A válaszadók szerint munkájuk hatékonyságát nagymértékben javítaná az informatikai fejlesztés (1-5-ig osztályozták az iskolában szokásos módon mennyire értenek egyet ezzel, 4es átlagot adtak, $\mathrm{N}=337$ ). Nyitott kérdésben kértem a szakembereket, hogy fejtsék ki, hogy milyen innovatív technológiát és megoldásokat látnának szívesen, mi segítené a munkájukat. Igen aktívak voltak a válaszadók, 110 szakember válaszolt erre a kérdésre. Fontos kiemelnem, hogy sokan itt jelezték, hogy első körben nem különleges innovációra lenne szükségük, hanem megfelelő mennyiségü és minőségü alapvető eszközökre és szoftverekre, infrastruktúrára, hiszen munkahelyükön még ezek sem adottak (számítógép, okostelefon, tablet, színes nyomtató, projektor, gyors, internet hozzáférés). Sokan nagyon elavult, lassú, rossz eszközöket használnak, sőt az is gyakori, hogy saját eszközökkel (laptop, okostelefon) dolgoznak. Általános, hogy 3 évnél régebbi eszközöket használnak a szociális szférában dolgozók, sokan mondták, hogy munkájuk az eszközpark elavultsága miatt nem elég hatékony, a régi gépek miatt napi szinten történik adatvesztés. Igényük van olyan megoldásokra, melyek egyszerüsítik, 
gyorsítják az adminisztrációt, mert „belefulladnak a papírba”, erre nagyon sokan panaszkodtak. Nagyon sok konkrét, innovációra vonatkozó igényt is megneveztek, az alábbi csoportokra oszthatóak az igényeik:

(1) Jó állapotú, müködőképes eszközök és erős wifi kapcsolat minden telephelyen (ez a klienseknek is nagyon fontos, mert ők is használják, használnák).

(2) További eszközök, például tabletek jegyzeteléshez, adatlapok vezetéséhez, munkahelyi okostelefon (előfizetéssel vagy kerettel), hogy a munkatársak ne a sajátjukat használják, okostévék (társalgóba, közösségi térbe), okos eszközök interaktív csoportfoglalkozás megtartásához. GPS-es óra, jelzőrendszer fejlesztése időseknek, demenseknek, projektor, hangfal, nyomtató, dokkoló rendszer, hordozható eszközök, amivel a kliens otthonában is tudnak szolgáltatást nyújtani, ügyintézni (akár olyan helyen is, ahol se áram, se internet), VR technológia.

(3) Papír alapú helyett lehetőleg teljes körü digitális dokumentáció, jogosultsági körökkel, digitális gondozási napló és adatlap vezetés, mely megkönnyíti az esetátadást, statisztikák és a kötelező adatszolgáltatások készítését (akár a KSH-val összehangolt rendszer), továbbá a problémák elemzését, ügyek összevetését, akár mintázatok megfigyelését. Többen úgy látták, hogy fontos lenne, hogy olyan megoldás szülessen (program, felület vagy applikáció), mely többféle eszközről elérhető, az adatvédelem biztosításával (elektronikus aláirás).

(4) Dokumentumcsomag, mely egyben tartalmazza az adott ellátásra / célcsoportra vonatkozó összes vezetendő aktuális dokumentációt, adatlapot (a válaszadók szerint jelenleg probléma, hogy sokszor úgy kell „összevadászni” a dokumentumokat, nehéz követni melyik az aktuális).

(5) Korszerü és az ellátási formákra szabott számlázó program (személyi térítési díjhoz), illetve elszámolást segítő programok.

(6) Ellátórendszer, szolgáltatások adatbázisa, nyilvántartási rendszer, várólistákat, kapacitásokat, várható üresedést naprakészen mutató felület, kliensek és várakozók adatait kezelő program (voltak, akik egészen konkrét igényeket is megfogalmaztak, például 235/1997. (XII. 17.) Korm. rendelet a gyámhatóságok, a területi gyermekvédelmi szakszolgálatok, a gyermekjóléti szolgálatok és a személyes gondoskodást nyújtó szervek és személyek által kezelt személyes adatokról vonatkozásában említette, hogy szükség lenne lekérdezhető, összesíthető adatbázisokra, illetve volt, aki az ellátotti rászorultságot megalapozó feltételek hatósági nyilvántartását igényelné).

(7) Jogszabály és pályázatfigyelés.

(8) Szoftver licencek, például Office programokhoz.

(9) Ellátottakkal való online kapcsolattartást és online konzultációt segítő megoldások.

(10) Iktató programok.

(11) Már meglévő rendszerek - például KENYSZI - fejlesztését is többen fontosnak látták.

(12) Módszertani segítség (etikai kérdésekkel kapcsolatos iránymutatás, pl. Viber, Messenger etikus használata a segítő folyamatokban).

(13) Informatikai képzés, digitális kompetenciák fejlesztése.

(14) Állás/munkahely és szociális bérlakás appok.

(15) Akadálymentesítés.

(16) Szakmai kapcsolattartás segítése. 
Arra vonatkozóan is tettem fel kérdést, hogy mit gondolnak, hogyan hívhatnánk fel a szociális munkások figyelmét a digitális kompetencia fontosságára. A válaszadók 72,1\%-a szerint fontos lenne, hogy a szociális munkás képzésbe építsék be a digitális készségek fejlesztését, 54,3\%uk szerint jó lenne, ha továbbképzéseken, tréningeken fejlesztenénk a szociális munkások tudását, készségeit, 50,7\%-uk szerint jó megoldás lenne könnyen érthető és hozzáférhető útmutatókat készíteni kifejezetten a szociális munkások számára. Szintén sokan támogatták a többi opciót is $(41,8 \%$ e-learninges képzéssel és online tananyagokkal, 41,8\% útmutatók a munkaadók, fenntartók számára, $41,5 \%$ a jó gyakorlatok díjazása és bemutatása, $26,1 \%$ team vagy intézményi szintủ szabályozással, illetve egyéb választ is megadhattak).

11. ábra. „Mit gondol, hogyan hívhatnánk fel a szociális munkások figyelmét a digitális kompetencia fontosságára?" kérdésre adott válaszok $(\%, N=337$, több választ is megjelölhettek)

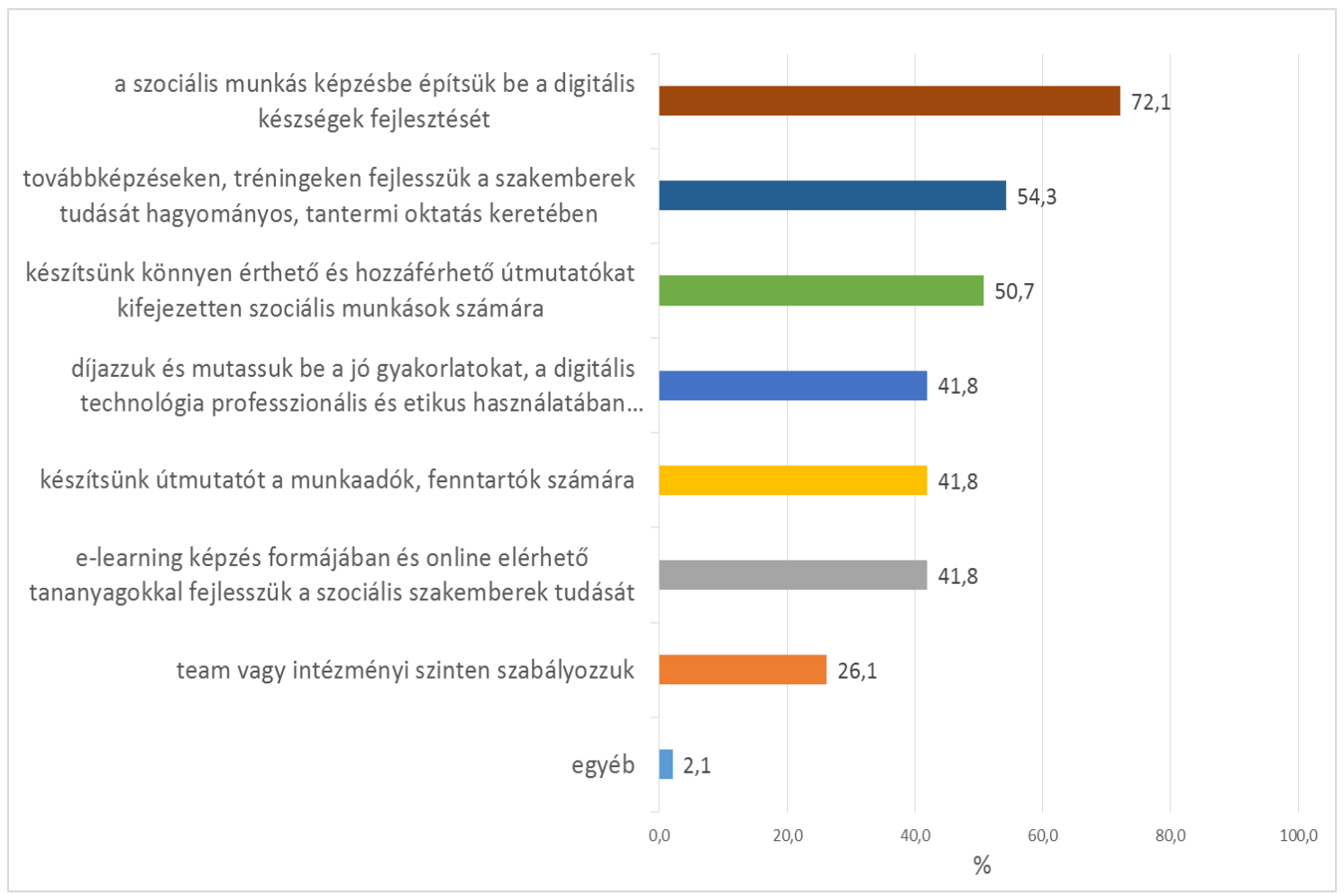

Forrás: saját szerkesztés

\section{Összegzés, javaslatok}

A tanulmányban a szociális szakemberek infokommunikációs technológia és közösségi média használatát vizsgáló kutatás eredményei kerültek bemutatásra. A kutatás célja volt annak megismerése, hogy munkájuk során a szociális szakemberek milyen mértékben és milyen formában használnak infokommunikációs technológiákat, illetve, hogy ezzel kapcsolatban milyen tapasztalataik vannak. Az igények felmérése mellett célom volt azonosítani azokat az akadályozó tényezőket is, melyek az IKT szociális munka gyakorlatába való integrációja előtt állnak. A kutatás kvantitatív módszerrel zajlott, az adatfelvétel 2020. január 28 és február 10. között, online önkitöltős kérdöívekkel történt, az alapsokaságot a szociális ágazatban dolgozó szakemberek alkották, az online kérdőívet 337 fö töltötte ki. 
Az eredmények szerint a szociális szakemberek attitüdjei pozitívak a technológia használattal kapcsolatban, érdeklődnek a technológiai újítások, innovációk iránt, szívesen próbálják ki azokat. Úgy látják, hogy a technológia használata megkönnyítheti a gondozást, kapcsolattartást, segítségével olyan célcsoportokat is elérhetnek, amelyeket korábban nem, vagy csak nehezen. Kiváló eszköznek tartják és használják is a közösségi médiát a gyors tudásmegosztásra, tanulásra, önfejlesztésre. A digitális technológia használata szakmai célokra igen elterjedt. Minden tizedik szakember online konzultációt biztosít, vagy online csoportot müködtet és minden negyedik segítő használja a digitális technológiát érdekképviseletre, közösségfejlesztésre. A kliensekkel való online kapcsolattartás gyakori $(41,8 \%)$ és ennek pozitív hozadékairól sokan beszámoltak, úgy tünik, ez nagyban segítheti a gondozást, a kliensek és hozzátartozóik elérését. Ugyanakkor minden negyedik válaszadóval elöfordult, hogy a kliense megzavarta a közösségi médiában a magánszféráját és, hogy letiltotta vagy törölte ismerősei közül az ellátottat. Internetes zaklatást már minden ötödik segítő tapasztalt. A közösségi oldalt használó válaszadók $88,6 \%$-ával előfordult már, hogy kliense ismerösnek jelölte a közösségi oldalon, amire teljesen változatos módon reagálnak, nagyon bizonytalannak tünnek abban, hogy mi számítana egy ilyen helyzetben megfelelő viselkedésnek. Ebben a szakemberek általában sem ágazati, sem intézményi szinten nem kapnak segítséget, útmutatást.

Számos innovációra vonatkozó igényt fogalmaztak meg a válaszadók, melyeket bemutattam a tanulmányban, azonban fontos kiemelnem, hogy ezek egyelöre elérhetetlennek tủnnek a szociális szakemberek számára. Bár úgy látják, hogy ezek a fejlesztések nagymértékben növelhetnék munkájuk hatékonyságát, először megfelelő mennyiségü és minőségü alapvető eszközökre és szoftverekre, infrastruktúrára lenne szükségük, hiszen munkahelyükön jelenleg gyakran még ezek sem adottak. Sokan nagyon elavult, lassú, rossz eszközöket használnak, sőt az is gyakori, hogy saját eszközökkel (laptop, okostelefon) dolgoznak. A megkérdezett szociális szakembereknek nagy igénye van új eszközök, programok beszerzésének támogatására, a szociális munkások közösségi média használatára vonatkozó szakmai, módszertani útmutatóra, ajánlásra, hozzáférésre az ellátórendszerre vonatkozó friss adatbázisokhoz és informatikai képzésre munkatársaiknak. Szívesen látnának olyan megoldásokat, melyek egyszerüsítik, gyorsítják az adminisztrációt.

A digitális technológia használati készségeiket összességében jónak ítélik meg, azonban a válaszokból az is kitűnik, hogy vannak hiányosságok, például a munkahelyi eszközöket a legtöbben nem védik megfelelően, továbbá gyakran keveredik a magánjellegü és szakmai kommunikációjuk, közösségi média használatuk. Informatikai, digitális kompetencia fejlesztő képzésen a válaszadók $71,5 \%$-a soha nem vett részt. A felsőfokú végzettségü válaszadók több, mint $70 \%$-a úgy ítéli meg, hogy tanulmányai során nem kapott megfelelő felkészítést az infokommunikációs technológiák használatára vonatkozóan. Ez fontos visszajelzés lehet a képzések alakítói számára, sokkal nagyobb hangsúlyt kellene fektetni a digitális írástudás és müveltség fejlesztésére. A megkérdezettek 72,1\%-a szerint fontos lenne, hogy a szociális munkás képzésbe építsék be a digitális készségek fejlesztését, 54,3\%-uk szerint jó lenne, ha továbbképzéseken, tréningeken fejlesztenénk a szociális munkások tudását, készségeit (akár online). Nagy szükség lenne a kliensek védelmében és a szolgáltatások megfelelő színvonalon történő, etikus biztosítása érdekében a technológiák segítésben történő alkalmazására vonatkozó módszertani útmutatók, szakmai ajánlások kidolgozására. A közösségi média használata során felmerülő szakmai és etikai kérdéseket meg kell vizsgálni, támogatni kell a szakemberek tudatos médiahasználatát. Szükséges a szociális munkás hallgatók képzésének és a szakemberek továbbképzéseinek átalakítása, hogy azokban nagyobb hangsúllyal jelenjen meg a digitális írástudás és müveltség fejlesztése. 
12. ábra. A szociális szakemberek digitális technológia és közösségi média használata,

SWOT analízis

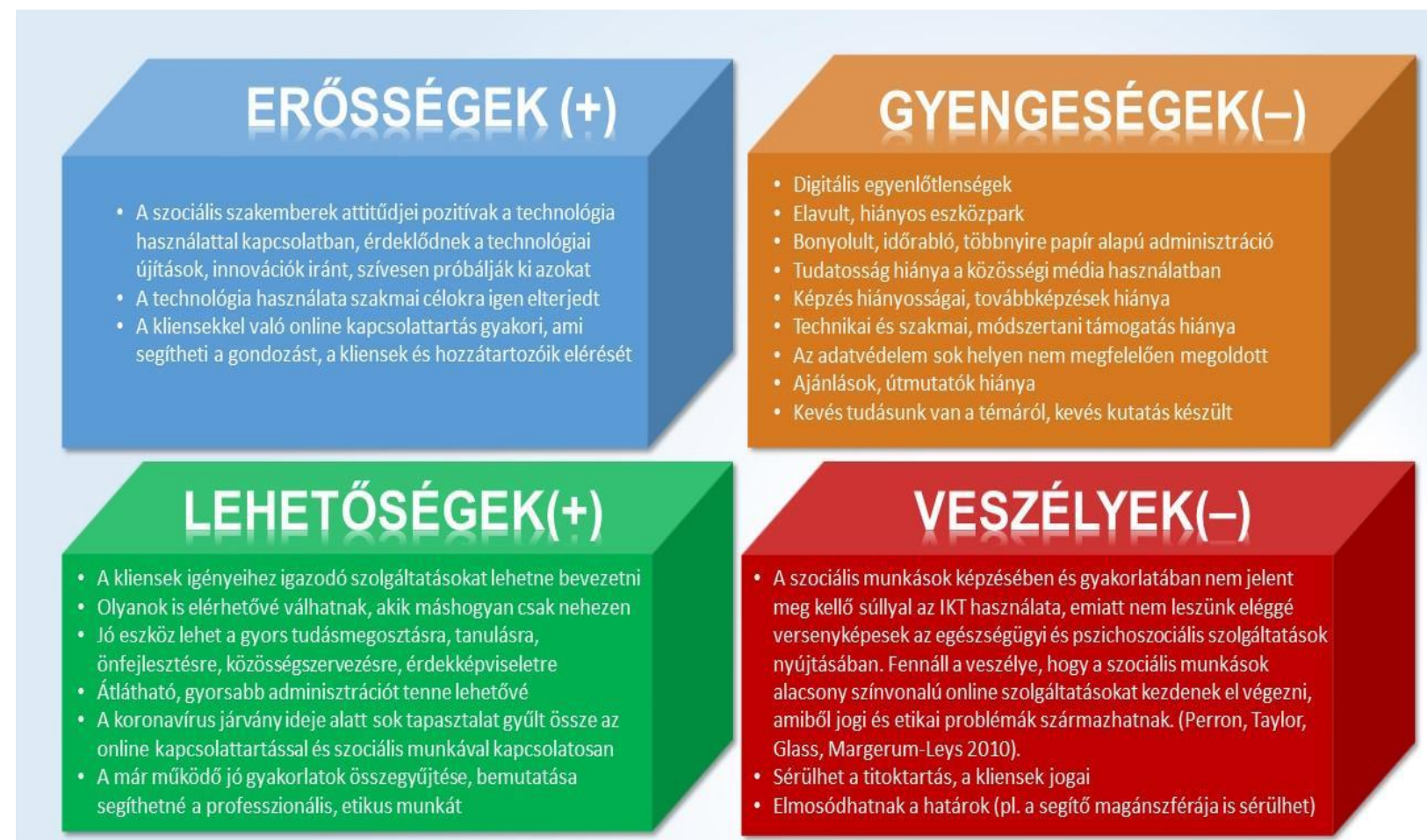

A szociális szakemberek digitális technológia és közösségi média használata, SWOT analizis

Forrás: saját szerkesztés

A kutatás eredményei egybecsengnek a 2000-es években készült magyar kutatások eredményeivel, úgy tünik, hogy a legtöbb területen nem történt jelentős változás. Így például Kéthelyi és Székely 2007-ben is úgy találta, hogy pozitív attitüdökkel közelítenek az infokommunikációs eszközök használatához a gyermekvédelemben dolgozó szakemberek, azonban jellemző a hardverhiány. A digitális írástudás szintjét akkor is erősen fejlesztendőnek látták, ám a szakemberek nem látták akkor sem a lehetőségét, hogy a közeljövőben ilyen jellegü képzéseken vehessenek részt (Kéthelyi - Székely 2007). Rácz Andrea és Gyarmati Andrea 2008-as kutatásának eredményei szerint is nagy igény volt az adminisztratív terhek csökkentésére, a hatékony munkavégzéshez szükségesnek tünt a munkavállalók digitális írástudásának fejlesztése, még több és jobb minőségü infokommunikációs eszköz biztosítása. A válaszadóik szükségesnek látták az informatikai képzéseket, szakmai segítséget, támogatást az eszközök használatához, illetve úgy régi, elavult gépeken dolgoztak, rossz szoftverekkel. A céges telefonok hiányára sokan panaszkodtak (Rácz - Gyarmati 2008). Molnár Dániel 2006ban a szociális felsőoktatásban az információs technológiák használatát, a hallgatók felkészültségét vizsgálta, és kutatásának eredményei szerint a hallgatók informatikai képzettsége végzéskor sem volt megfelelő. (Molnár 2006). Mindez úgy tủnik az utóbbi tíztizenöt évben szintén nem sokat változott, válaszadóim is ezekről a problémáról és igényekről számoltak be. Héra Gábor és Ligeti György 2005-ös kutatásában, interjúk és résztvevő megfigyelések alapján még arról számoltak be, hogy a szociális szakemberek körében nagyfokú ellenállás, idegenkedés van a számítógéppel és a digitális rendszerekkel szemben, kutatásom eredményei szerint ez a hozzáállás ma már egyáltalán nem domináns, erősebb a nyitottság, az érdeklődés, szívesen használják a technológiát, próbálják ki az újításokat és már nem csak az 
adminisztráció jut a segítők eszébe a számítógépről. Az adatbiztonsági, adatvédelmi problémák amelyeket tapasztaltak - például, hogy számítógépeiket nem védik jelszóval - még ma is jellemzőek, ahogyan a túl sok adminisztrációra fordított idő és az elavult hardverpark problémája is. (Héra - Ligeti 2005) Igények közt megjelentek az okoseszközök, tabletek, okostelefonok, illetve a szociális szakemberek közösségi média használata és a kliensekkel való online kommunikáció és kapcsolattartás is elterjedt időközben.

Érdekesség, hogy a vizsgálat éppen a COVID-19 koronavírus járvány előtti hetekben zajlott, így az eredményekből pillanatképet kaphatunk arról, hogy 2020. év elején a szociális szakemberek mire és hogyan használták a digitális technológiát és a közösségi médiát, milyen volt a kliensekkel való online kapcsolatuk. Azonban az azóta eltelt néhány hónapban is hatalmas változások történtek: sok esetben az online kapcsolattartás, sőt, az online segítés is preferált formává vált, olyan intézményekben és ellátástípusokban is elkezdték használni a technológia által kínált lehetőségeket, ahol korábban idegenkedtek ezektől. Emiatt érdemes lenne a közeljövőben felmérni, hogy a pandémiás helyzet mennyiben változtatott a szociális szakemberek technológia és közösségi média használatán, milyen tapasztalatok voltak ebben az időszakban. Mindezt nem csak a segítők, hanem a kliensek oldaláról is meg kell vizsgálnunk, különös tekintettel a digitális egyenlötlenségekre.

\section{Irodalomjegyzék}

BELLUOMINI, E. (2013): Technology changing the face of social work. The New Social Worker, 20(2), http://www.socialworker.com/featurearticles/technologyarticles/Technology Changing the Face of Social Work/.

BOUTIN, F., CHINIEN, C. (2003): "Bridging the Cognitive Divide in ICT-Mediated Learning", Advanced Learning Technologies, IEEE International Conference, http://www.computer.org/portal/web/csdl/doi/10.1109/ICALT.2003.1215154.

BRITISH ASSOCIATION OF SOCIAL WORKERS (2012): BASW Social Media Policy, http://cdn.basw.co.uk/upload/basw 14300-2.pdf (utolsó letöltés: 2017. 06. 25.).

BULLOCK, A. N., COLVIN, A. D. (2015): Communication Technology Integration into Social Work Practice. Advances in Social Work, 16 (1).

https://journals.iupui.edu/index.php/advancesinsocialwork/article/view/18259/19916.

DIMAGGIO P., HARGITTAI, E. (2001): From the 'Digital Divide' to 'Digital Inequality': Studying Internet Use as Penetration Increases. Princeton University, Woodrow Wilson School of Public and International Affairs, Center for Arts and Cultural Policy Studies., Working Papers Series 15. https://culturalpolicy.princeton.edu/sites/culturalpolicy/files/wp15 dimaggio hargittai.pdf Utolsó letöltés: 2020.05.09.

ERDŐS A. (2015): Digitális egyenlőtlenségek és eredményesség - PISA 2015. Oktatási hivatal https://www.oktatas.hu/pub bin/dload/KEJ/Digitalis egyenlotlensegek PISA2015.pdf Utolsó megtekintés: 2020.05.03.

GOLDMANN R. (2014) Humánerőforrás helyzetkép a szociális ágazatban. Kézirat. 
HÉRA G., LIGETI GY. (2005): Igények és hiányok - informatika a szociális szférában. Esély, 16(6).

106-120. http://www.esely.org/kiadvanyok/2005_6/hera.pdf (utolsó letöltés: 2017. 06. 25.).

KÉTHELYI G., SZÉKELY L. (2007): A gyermekvédelmi rendszer információs társadalmi felkészültsége. Társadalomkutató és tanácsadó betéti társaság. Kézirat.

KOLMES, K, TAUBE, D. O. (2014): Seeking and Finding Our Clients on the Internet: Boundary Considerations in Cyberspace. Professional Psychology: Research and Practice, 45 (1), 3-10. http://www.apa.org/pubs/journals/features/pro-a0029958.pdf

MISHNA, F., BOGO, M., ROOT, J., FANTUS, S. (2014): Here to stay: Cyber communication as a complement in social work practice. Families in Society: The Journal of Contemporary Social Services, 95(3). 179-186.

MOLNÁR D.(2006): Információs technológiák a szociális felsőoktatásban. Információs Társadalom, 6(2), http://epa.oszk.hu/01900/01963/00017/pdf/infotars_2006_06_02_077097.pdf (utolsó letöltés: 2017. 06.25.).

NATIONAL ASSOCIATION OF SOCIAL WORKERS \& ASSOCIATION OF SOCIAL WORK BOARDS (2005): Standards for Technology and Social Work Practice, http://www.socialworkers.org/practice/standards/NASWTechnologyStandards.pdf (utolsó letöltés: 2017. 06.25.).

PERRON, B. E., TAYLOR, H. O., GLASS, J. E., MARGERUM-LEYS, J. (2010): Information and Communication Technologies in Social Work. Advances in Social Work, 11(2). 67-81. https://www.ncbi.nlm.nih.gov/pmc/articles/PMC3117433/

READRON, C. (2010): Data Driven, People Focused - Technology Takes on Social Work. Social Work Today, 10 (6). 6. http://www.socialworktoday.com/archive/111610p6.shtml.

RÁCZ A., GYARMATI A. (2008): Beszámoló a gyámhatósági feladatokat ellátó szervezetek informatikai ellátottságáról. Kézirat.

SZOCIÁLIS SZAKMAI SZÖVETSÉG (2016): A Szociális Szakmai Szövetség Etikai Kollégiuma által 2015-16-ban átdolgozott Szociális munka etikai kódexe, 20. és 23. pont, http://3sz.hu/sites/default/files/Etikai.pdf

TERNAY A. (2017): A szociális munka etika oktatása. Párbeszéd, 4 (1). https://ojs.lib.unideb.hu/parbeszed/article/view/5923/5535

TÓTH A. P. (2017a): Infokommunikációs technológiák használata a szociális munka gyakorlatában. Párbeszéd 4 (2) https://ojs.lib.unideb.hu/parbeszed/article/view/5945/5556

TÓTH A. P. (2017b): A mentálhigiéné fejlesztésének lehetőségei a telemedicina segítségével. Metszetek 6 (2) 139-166. http://metszetek.unideb.hu/files/tanulmany_139-166.pdf

TÓTH A. P. (2017c): Professzionális és etikus IKT használat a szociális munka gyakorlatában - a nemzetközi ajánlások áttekintése. Párbeszéd 4 (3)

https://ojs.lib.unideb.hu/parbeszed/article/view/5951/5562 


\section{Internetes források:}

http1

https://www.basw.co.uk/media/news/2019/jun/basw-and-scie-survey-digital-capabilities-social-work (BASW\&SCIE survey on digital capabilities in social work. 2019; Látogatva: 2019. december 31.)

http2

https://ec.europa.eu/eurostat/databrowser/view/tin00028/default/table?lang=en (EUROSTAT: Internet use by individuals, \% of individuals aged 16 to 74. 2019; Látogatva: 2020.05.19.)

http3

https://ec.europa.eu/eurostat/tgm/table.do?tab=table\&plugin=1\&language=en\&pcode=tin00127 (EUROSTAT: Individuals using the internet for participating in social networks, $\%$ of individuals aged 16 to 74. 2019; Látogatva: 2020.05.03.)

http4

https://www.ksh.hu/docs/hun/xstadat/xstadat_evkozi/e_qli039c.html KSH STADAT táblák: 2.1.49.

Az alkalmazásban állók létszáma a nemzetgazdaságban a közfoglalkoztatottak nélkül;

Látogatva: 2020.05.03.

http5

https://www.statista.com/statistics/272014/global-social-networks-ranked-by-number-of-users/

(STATISTA: Most popular social networks ranked by number of active users; Látogatva: 2020.05.03.)

\section{Jogszabályok:}

1/2000. (I. 7.) SzCsM rendelet a személyes gondoskodást nyújtó szociális intézmények szakmai feladatairól és müködésük feltételeiről

\section{Függelék}

1. táblázat. A felhívás az alábbi felületeken és időpontokban került megosztásra

\begin{tabular}{|c|c|c|}
\hline Megnevezés & Megosztás dátuma & $\begin{array}{l}\text { Követők, ke dvelök vagy tagok } \\
\text { száma a me gosztás napján }\end{array}$ \\
\hline Szociális Szakmai Szövetség közösségi oldala & 2020.01 .29 & 8240 kedvelö, 8371 követö \\
\hline Szociális Szakemberek zárt facebook csoportia & 2020.01 .28 & $7565 \mathrm{tag}$ \\
\hline Szociális Szakemberek e-mailes levelezölistája & 2020.01 .28 & 1874 tag \\
\hline ELTE TáTK Szociális Munka Tanszék oldala & 2020.01 .28 & 1669 kedvelö, 1704 követö \\
\hline Szociális Munkások Demokratikus Szakszervezete facebook oldala & 2020.01 .30 & 3691 kedvelö, 3721 követö \\
\hline Szociális Területen Dolgozók Szakszervezete facebook oldala & 2020.01 .30 & 3391 kedvelö, 3376 követö \\
\hline ,Közösen a szociális területért” facebook oldal & 2020.01 .30 & 5819 kedvelö, 5686 követö \\
\hline $\begin{array}{l}\text { „Szociális gondozók/dolgozók,szakgondozók, demencia gondozók" } \\
\text { facebook csoport }\end{array}$ & 2020.01 .28 & $7388 \operatorname{tag}$ \\
\hline Szociális és Gvermekióléti alapellátások facebook oldal & 2020.01 .29 & 3849 kedvelö, 3910 követö \\
\hline Támogató szolgálatok privát facebook csoport & 2020.02 .03 & $425 \operatorname{tag}$ \\
\hline A Magyar Vöröskereszt belsô szakmai levelezölistái & 2020.02 .03 & $76 \operatorname{tag}$ \\
\hline Személves facebook oldalam & 2020.01 .28 & 524 ismerös, 29 megosztás \\
\hline
\end{tabular}

